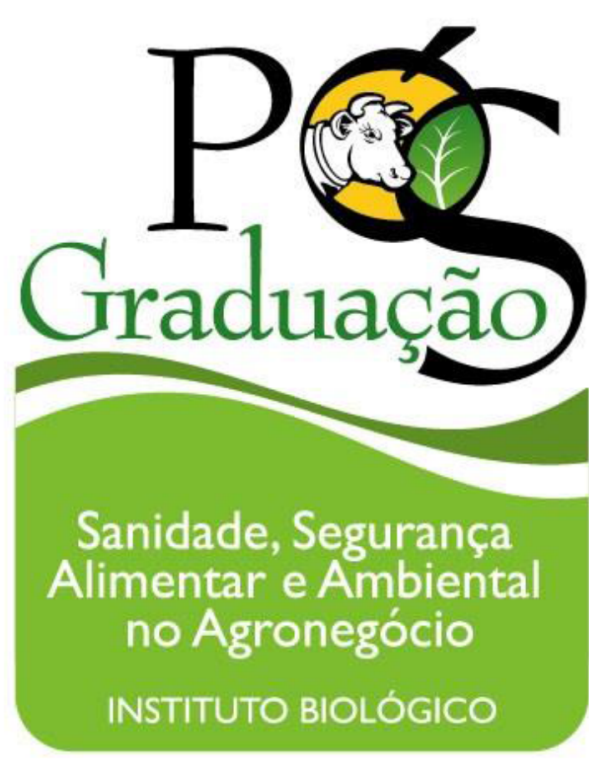

\title{
AVALIAÇÃO DA EFICIENCIA DA VACINAÇÃO CONTRA A FEBRE AFTOSA NO ESTADO DE SÃO PAULO, BRASIL
}

\author{
Gabriel Adrian Sanchez Torres
}

Dissertação apresentada ao Instituto Biológico, da Agência Paulista de Tecnologia dos Agronegócios, como parte das exigências para obtenção do título de Mestre em Sanidade, Segurança Alimentar e Ambiental no Agronegócio.

Área de Concentração: Segurança Alimentar e Sanidade no Agroecossistema.

Orientadora: Profa. Dra. Edviges Maristela Pituco 


\title{
INSTITUTO BIOLÓGICO
}

\author{
PÓS-GRADUAÇÃO
}

\section{AVALIAÇÃO DA EFICIENCIA DA VACINAÇÃO CONTRA A FEBRE AFTOSA NO ESTADO DE SÃO PAULO, BRASIL}

\author{
Gabriel Adrian Sanchez Torres
}

Dissertação apresentada ao Instituto Biológico, da Agência Paulista de Tecnologia dos Agronegócios, como parte das exigências para obtenção do título de Mestre em Sanidade, Segurança Alimentar e Ambiental no Agronegócio.

Área de Concentração: Segurança Alimentar e Sanidade no Agroecossistema.

Orientadora: Profa. Dra. Edviges Maristela Pituco 
Eu, Gabriel Adrian Sanchez Torres, autorizo o Instituto Biológico (IB-APTA), da Secretaria de Agricultura e Abastecimento do Estado de São Paulo, a disponibilizar gratuitamente e sem ressarcimento dos direitos autorias, o presente trabalho acadêmico, de minha autoria, no portal, biblioteca digital, catálogo eletrônico ou qualquer outra plataforma eletrônica do IB para fins de leitura, estudo, pesquisa e/ou impressão pela Internet desde que citada a fonte.

Assinatura:

Data

Dados Internacionais de Catalogação na Publicação (CIP) Secretaria de Agricultura e Abastecimento do Estado de São Paulo Núcleo de Informação e Documentação - IB

Torres, Gabriel Adrian Sanchez.

Avaliaçăo da eficiência da vacinaçăo contra a febre aftosa no estado de Săo

Paulo, Brasil. / Gabriel Adrian Sanchez Torres. - Săo Paulo, 2018.

$55 \mathrm{p}$.

doi: 10.31368/PGSSAAA.2018.D.GT015

Dissertaçăo (Mestrado). Instituto Biológico (Săo Paulo). Programa de Pós-

Graduaçăo.

Área de concentraçăo: Segurança Alimentar e Sanidade no Agroecossistema.

Linha de pesquisa: Gestâo Sanitária e Ambiental na produçăo animal.

Orientador: Edviges Maristela Pituco.

Versăo do titulo para o inglês: Evaluation of the vaccination efficiency against

foot-and-mouth disease in the State of Săo Paulo, Brazil.

1. Febre aftosa 2. Vacinaçăo 3. Cobertura imunológica 4. ELISA-CFL

I. Torres, Gabriel Adrian Sanchez II. Pituco, Edviges Maristela III. Instituto Biológico (Săo Paulo) IV. Título. 

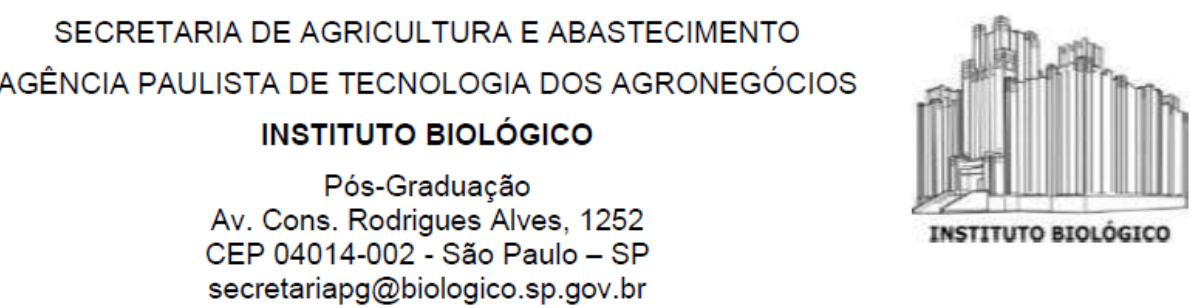

\section{FOLHA DE APROVAÇÃO}

\section{Gabriel Adrian Sanchez Torres}

Título: Avaliação da eficiência da vacinação contra a febre aftosa no Estado de São Paulo, Brasil.

Orientadora: Edviges Maristela Pituco

Aprovada em:

Dissertação apresentada ao Instituto Biológico, da Agência Paulista de Tecnologia dos Agronegócios, como parte das exigências para obtenção do título de Mestre em Sanidade, Segurança Alimentar e Ambiental no Agronegócio.

Área de Concentração: Segurança Alimentar e Sanidade no Agroecossistema.

\section{Banca Examinadora}

Assinatura:

*Prof. Dr:

*Instituição:

Assinatura:

*Prof. Dr:

*Instituição:

Assinatura:

*Prof. Dr:

*Instituição: 


\section{AGRADECIMENTOS}

A Deus, pela eterna proteção;

À minha esposa, pelo companheirismo e paciência, e às minhas filhas, pelo simples fato de existirem;

Aos meus pais, por garantirem as melhores das condições para que eu trilhasse meu caminho até aqui, e à minha irmã, pela amizade;

Aos meus amigos de toda vida, em especial aos do colégio Pio XII e da $64^{\mathrm{a}}$. Turma de Medicina Veterinária da FMVZ/USP;

Aos meus amigos e colegas do MAPA, pela convivência, companheirismo e aprendizado;

Aos meus colegas de Pós-Graduação do Instituto Biológico, pela excelente convivência nos últimos anos;

À professora Edviges Maristela Pituco, por ser uma verdadeira mestre, na acepção da palavra;

À professora Claudia Del Fava, pelo apoio, confiança e companheirismo;

Aos demais professores e funcionários do Instituto Biológico, pela calorosa acolhida. 


\section{EPÍGRAFE}

"Quando você educa um psicopata, tudo o que ganha é um psicopata educado"

Gregg McCrary 


\section{RESUMO \\ TORRES, Gabriel Adrian Sanchez - Avaliação da eficiência da vacinação contra a}

febre aftosa no estado de São Paulo, Brasil. 2018. 55 f. Dissertação (Mestrado em Sanidade, Segurança Alimentar e Ambiental no Agronegócio) - Instituto Biológico, Agência Paulista de Tecnologia dos Agronegócios, Secretaria de Agricultura e Abastecimento do Estado de São Paulo, São Paulo, 2018.

A febre aftosa é uma doença infectocontagiosa de rápida dispersão, que afeta diversas espécies domésticas. As estratégias de controle e erradicação da doença adotadas na maioria dos países do continente incluem a vacinação massal da população susceptível. Para avaliar a resposta imune de animais vacinados contra a febre aftosa, foi desenvolvida a técnica de ELISA de Competição em Fase Líquida (CFL), padronizada pelo Centro Panamericano de Febre Aftosa para uso na América do Sul, diante dos sorotipos presentes no Continente - A24 Cruzeiro, O1 Campos e C3 Indaial. No presente trabalho, o rebanho bovino do Estado de São Paulo, Brasil, foi submetido a um estudo transversal para a avaliação da imunidade populacional frente aos três sorotipos do vírus da febre aftosa presentes na formulação da vacina. A amostra foi estratificada segundo a idade, com dois grupos etários (animais entre 6 e 12 meses e animais de 13 a 24 meses), e segundo o tamanho do rebanho, com outros dois grupos (rebanhos de até 50 cabeças e rebanhos com mais de 50 cabeças). Para determinação do tamanho da amostra, considerou-se um nível de confiança de 95,0\%, sensibilidade e especificidade do teste de 83,3\%, erro de amostragem de $10,0 \%$ e erro absoluto de 8,5\%. Em relação às prevalências esperadas, adotou-se a expectativa de proteção de $70 \%$ para bovinos entre 6 e 12 meses de idade nos rebanhos com até 50 animais, $75 \%$ para bovinos entre 6 e 12 meses de idade nos rebanhos com mais de 50 animais, $80 \%$ para bovinos entre 13 e 24 meses de idade nos rebanhos com até 50 animais e $85 \%$ para bovinos entre 13 e 24 meses de idade nos rebanhos com mais de 50 animais. No total, foram colhidas amostras de 199 animais divididos em 51 propriedades. Os resultados demonstraram índices de proteção de 78,2\% para o vírus $\mathrm{O}$, $79,9 \%$ para o vírus A e 82,6\% para o vírus C - estando os índices para os sorotipos A e O ligeiramente abaixo dos 80,0\%, valor mínimo preconizado pelo MAPA.

Palavras chave: Febre aftosa. Vacinação. Cobertura imunológica. ELISA-CFL. 


\begin{abstract}
Torres, Gabriel Adrian Sanchez - Evaluation of the vaccination efficiency against footand-mouth disease in the State of São Paulo, Brazil. 2018. 55 f. Dissertação (Mestrado em Sanidade, Segurança Alimentar e Ambiental no Agronegócio) - Instituto Biológico, Agência Paulista de Tecnologia dos Agronegócios, Secretaria de Agricultura e Abastecimento do Estado de São Paulo, São Paulo, 2018.
\end{abstract}

Foot-and-mouth disease is an infectious disease of fast dissemination, affecting several domestic species. The disease control and eradication strategies adopted in most of the continent countries include the vaccination of the susceptible population. To evaluate the immune response of animals vaccinated against foot-and-mouth disease, the Liquid Phase Competition (CFL) ELISA technique was developed, being later standardized by the Pan American Foot-and-Mouth Disease Center for its use in South America, considering the virus subtypes present in the Continent - A24 Cruzeiro, O1 Campos and Indaial C3. In the present study, the bovine herd of the State of São Paulo, Brazil, was submitted to a cross-sectional study to evaluate the population immunity against the three foot-and-mouth disease virus serotypes present in the vaccine formulation. The sample was stratified according to age, with two age groups (animals between 6 and 12 months and animals from 13 to 24 months), and according to the size of the herd, with two other groups (herds of up to 50 animals and herds larger than 50 animals). To determine the sample size, the following parameters were considered: confidence level of $95.0 \%$, test sensitivity and specificity of $83.3 \%$, sampling error of $10.0 \%$ and absolute error of $8.5 \%$. Regarding the expected prevalences, the following protection expectation were considered: $70 \%$ for cattle between 6 and 12 months in herds with up to 50 animals, $75 \%$ for cattle between 6 and 12 months in herds with more than 50 animals, $80 \%$ for cattle between 13 and 24 months in herds with up to 50 animals and $85 \%$ for cattle between 13 and 24 months in herds with more than 50 animals. In total, 199 animals were sampled, divided among 51 properties. The results showed protection rates of $78.2 \%$ for virus $\mathrm{O}, 79.9 \%$ for virus $\mathrm{A}$ and $82.6 \%$ for virus $\mathrm{C}-$ being the rates for the serotypes $\mathrm{A}$ and $\mathrm{O}$ slightly below 80,0\%, minimun value recommended by MAPA.

Keywords: Foot and mouth disease. Vaccination. Immunological coverage. ELISACFL. 
LISTA DE FIGURAS

\begin{tabular}{|c|l|c|}
\hline Figura & \multicolumn{1}{|c|}{ Título } & Página \\
\hline 1 & Patogenia da febre aftosa em bovinos & 19 \\
\hline 2 & Evolução teórica da febre aftosa em um bovino infectado & 20 \\
\hline 3 & $\begin{array}{l}\text { Mapa dos países segundo status sanitário em relação à febre } \\
\text { aftosa }\end{array}$ & 20 \\
\hline 4 & $\begin{array}{l}\text { Status sanitário dos países da América do Sul em relação à } \\
\text { febre aftosa }\end{array}$ & 21 \\
\hline 5 & $\begin{array}{l}\text { Mapa das estratégias de vacinação contra febre aftosa } \\
\text { adotadas no Brasil }\end{array}$ & 28 \\
\hline 6 & $\begin{array}{l}\text { Calendário nacional de vacinação de bovinos e bubalinos } \\
\text { contra a febre aftosa }\end{array}$ & 29 \\
\hline 7 & $\begin{array}{l}\text { Índices nacionais de coberturas vacinais de bovinos e } \\
\text { bubalinos contra a febre aftosa }\end{array}$ & 31 \\
\hline 8 & $\begin{array}{l}\text { Resultados da vacinação contra Febre Aftosa do primeiro } \\
\text { semestre de 2018 }\end{array}$ & 43 \\
\hline 9 & $\begin{array}{l}\text { Municípios selecionados para o estudo e a concentração de } \\
\text { propriedades selecionadas por município }\end{array}$ & 48 \\
\hline 10 & Formulário utilizado para a colheita de amostras & 50 \\
\hline 11 & $\begin{array}{l}\text { Esquematização do teste de ELISA-CFL na placa de } \\
\text { microtitulação, com respectivas diluições. }\end{array}$ \\
\hline
\end{tabular}


LISTA DE TABELAS

\begin{tabular}{|c|l|c|}
\hline Tabela & \multicolumn{1}{|c|}{ Título } & Página \\
\hline 1 & $\begin{array}{l}\text { Estratificação das amostras e porcentagem esperada se protegidos } \\
\text { por estado }\end{array}$ & 40 \\
\hline 2 & Distribuição das amostras por municípios & $41 / 42$ \\
\hline 3 & Distribuição dos animais amostrados por rebanho e município & $43 / 44$ \\
\hline 4 & $\begin{array}{l}\text { Número de Unidades Regionais (EDAs) envolvidas nos trabalhos } \\
\text { de campo }\end{array}$ & 45 \\
\hline 5 & $\begin{array}{l}\text { Prevalências aparente e corrigida e intervalo de confiança para } \\
\text { prevalência corrigida referentes ao total de bovinos protegidos, } \\
\text { segundo tipo de vírus }\end{array}$ & 56 \\
\hline
\end{tabular}




\section{LISTA DE GRÁFICOS}

\begin{tabular}{|c|l|c|}
\hline Gráfico & \multicolumn{1}{|c|}{ Título } & Página \\
\hline 1 & Número de focos de febre aftosa no Brasil, de 1970 a 2018 & 27 \\
\hline 2 & $\begin{array}{l}\text { Quantidade de amostras de animais protegidos e não protegidos, } \\
\text { segundo tamanho rebanho }\end{array}$ & 54 \\
\hline 3 & $\begin{array}{l}\text { Quantidade de amostras de animais protegidos e totais, segundo } \\
\text { idade }\end{array}$ & 55 \\
\hline
\end{tabular}


LISTA DE ANEXOS

\begin{tabular}{|c|c|c|}
\hline Anexo & Título & Página \\
\hline 1 & Materiais necessários para a realização do ensaio de ELISA-CFL & 73 \\
\hline
\end{tabular}




\section{LISTA DE SIGLAS}

ANTAQ - Agência Nacional de Transportes Aquaviários

APHIS - Animal and Plant Health Inspection Service

BEI - Etilenimina binária

BHK - Baby hamster kidney

CAD - Centro de Análises e Diagnóstico

CATI - Coordenadoria de Assistência Técnica Integral do Estado de São Paulo

CDA - Coordenadoria de Defesa Agropecuária do Estado de São Paulo

CGNA - Centro de Gerenciamento da Navegação Aérea

DO - Densidade Óptica

EDA - Escritório de Defesa Agropecuária

EITB - Western Blot de Imunoeletrotransferência

ELISA - Ensaio de Imunoabsorção Enzimática

ELISA-3ABC - Ensaio de Imunoabsorção Enzimática do Anticorpo contra a Proteína $3 \mathrm{ABC}$

ELISA-CFL - Ensaio de Imunoabsorção Enzimática de Competição em Fase Líquida

FAESP - Federação de Agricultura do Estado de São Paulo

IICA - Instituto Interamericano de Cooperação Agrícola

LANAGRO - Laboratório Nacional Agropecuário

MAPA - Ministério da Agricultura, Pecuária e Abastecimento

MGAP - Ministerio de Agricultura, Ganaderia y Pesca

OIE - Organização Mundial de Saúde Animal

OPAS/OMS - Organização Pan-americana de Saúde/Organização Mundial de Saúde 
ORF - Open Reading Frame

PANAFTOSA - Centro Pan-americano de Febre Aftosa

PPA - Plano Plurianual

PC - Proteínas Capsidais

PNC - Proteínas Não Capsidais

PNEFA - Programa Nacional de Erradicação da Febre Aftosa

RNA - Ácido Ribonucleico

RPM - Rotações Por Minuto

SENASA - Servicio Nacional de Sanidad Agraria

SVO - Serviço Veterinário Oficial

WRL - World Laboratory Reference 


\section{LISTA DE SÍMBOLOS}

${ }^{\circ} \mathrm{C}$ - Graus Celsius

$\%$ - Porcentagem

$\mathrm{m}-$ Metro

$\mathrm{mL}$ - Mililitros

nm - Nanômetros

$\mu \mathrm{L}-$ Microlitros

: - Proporção de relação 


\section{SUMÁRIO}

1. INTRODUÇÃ

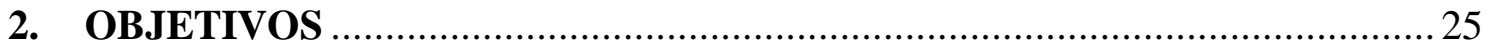

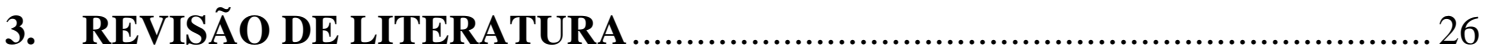

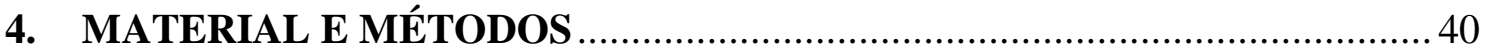

4.1. PARÂMETROS PARA DETERMINAÇÃO DO TAMANHO DA AMOSTRA . 40

4.2. TAMANHO E DISTRIBUIÇÃO DA AMOSTRA ............................................ 41

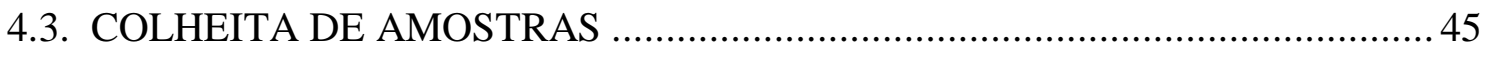

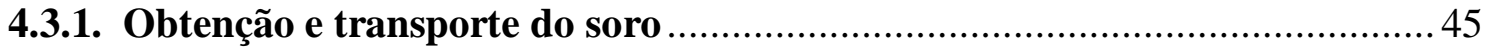

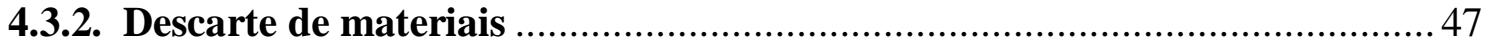

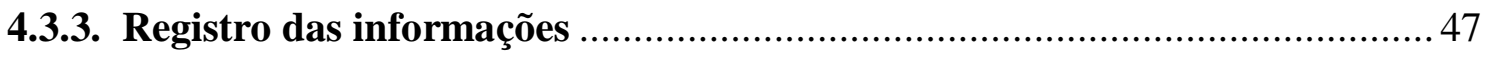

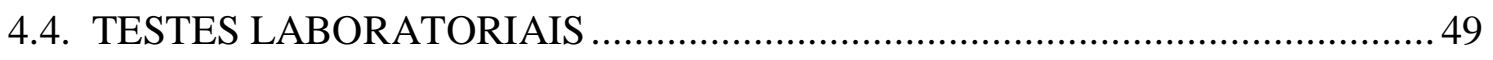

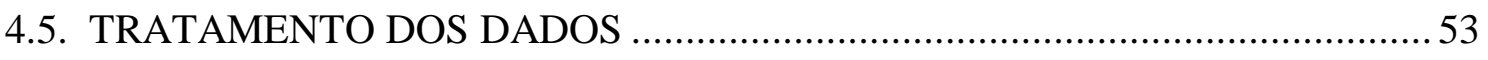

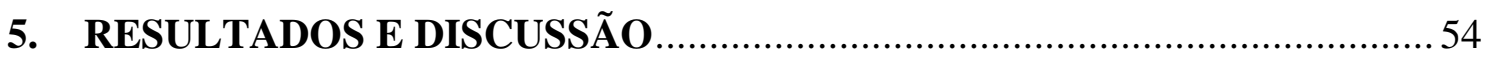

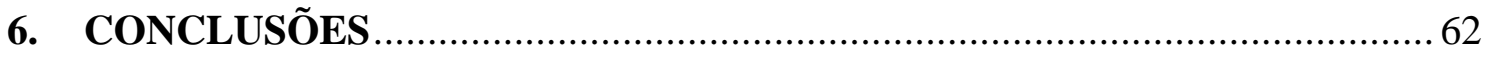

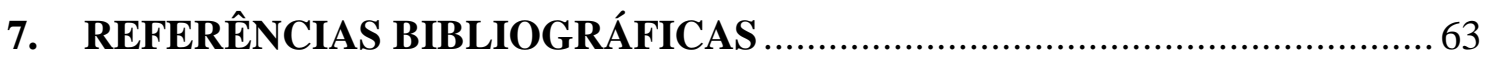

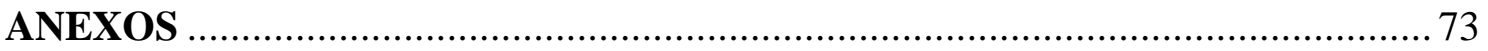




\section{INTRODUÇÃO}

A febre aftosa é uma doença infectocontagiosa que acomete bovinos, bubalinos, suínos, caprinos, ovinos e uma extensa gama de animais silvestres, majoritariamente biungulados, embora ocasionalmente afete outros animais, como a anta, a capivara e o elefante (OIE, 2018). É uma doença de curso agudo, altamente contagiosa e de rápida dispersão, causando diversos prejuízos à pecuária (PITUCO, 2012, p.1). Além do impacto negativo na produção de carne e leite, os custos e prejuízos relacionados à ocorrência de febre aftosa incluem a perda de mercados importadores de produtos de origem animal, os gastos inerentes ao controle da doença e à indenização de animais descartados e a redução das atividades ou o fechamento de indústrias de abate e processamento de produtos de origem animal, entre outros (KNIGHT-JONES; RUSHTON, 2013, p. 163-171). É considerada a doença de maior impacto em saúde animal em todo o mundo (LONGJAM et al., 2011, p.1). Sua primeira descrição se deu na Itália, em 1546, tendo sido pela primeira vez detectada na América do Sul em 1870 e, posteriormente, no Brasil, em 1895, no município de Uberaba (GRUBMAN; BAXT, 2004, p. 465; LYRA; SILVA, 2004, p. $565)$.

A febre aftosa é causada por um vírus de RNA fita simples, não envelopado, do gênero Aphtovírus e da família Picornaviridade. A conformação do vírus é icosaédrica, e seu tamanho é bastante reduzido - cerca de 25-30 nm em diâmetro (FORREST et al., 2014, p. 2651). O RNA, que corresponde a $31 \%$ da constituição total do vírus, é extremamente compactado e de conformação esférica. A cápside é formada por uma estrutura polipeptídica composta por quatro proteínas: VP1, VP2, VP3 e VP4. Esse polipeptídeo repete-se por sessenta vezes na formação da cápside, que apresenta as proteínas VP1, VP2, VP3 (externas) e VP4 em sua face interna. A proteína VP1 é a mais importante na modulação da resposta imunológica do hospedeiro (JAMAL; BELSHAM, 2013, p.2).

Por ser um RNA vírus, é particularmente susceptível a mutações, o que explica a grande quantidade de sorotipos, subtipos e cepas existentes do agente (GRUBMAN; BAXT, 2004, p. 473). Atualmente, são reconhecidos sete sorotipos do vírus: A, O, C, SAT1, SAT2, SAT3 e ASIA1, sendo que os três primeiros já foram diagnosticados na América do Sul (DOEL, 2003, p. 82). Dentre esses, já foram descritos 11 subtipos para o sorotipo A, 32 subtipos para o sorotipo O e 5 subtipos para o sorotipo C. No Brasil, os 
subtipos mais importantes são o A24 Cruzeiro, o O1 Campos e o C3 Indaial, que entram na composição da vacina de uso obrigatório no país (LYRA; SILVA, 2004, p. 567-573).

Os sinais clínicos da febre aftosa incluem a formação de vesículas no espaço interdigital, coroa do casco, gengivas, lábios, palato, língua e úbere, febre alta (até $40^{\circ} \mathrm{C}$ ), anorexia e depressão (OIE, 2018). Como consequência da formação e posterior rompimento das vesículas, geralmente observa-se sialorreia e secreção nasal. $O$ rompimento das vesículas também leva à formação de lesões ulcerativas na boca e língua, que se tornam altamente sensíveis, o que costuma ocasionar uma brusca queda no consumo de alimentos. Quando as lesões se localizam nos cascos, há dificuldades de locomoção e claudicação. A redução na ingesta, somada a uma locomoção limitada - e consequente diminuição da procura de alimento - leva a consideráveis reduções da produção leiteira e do ganho de peso. Vesículas rompidas no úbere e nos tetos também podem facilitar a ocorrência de mastites secundárias. Em bezerros, pode ocorrer miocardite, levando o animal à morte. Em suínos, as lesões costumam concentrar-se nas patas, sendo quase sempre bastante severas. De modo geral, os suínos são mais susceptíveis à manifestação clínica da doença, seguido de bovinos e bubalinos. Em caprinos e ovinos, os sinais costumam ser menos pronunciados, embora essa condição varie com a cepa e o grau de imunidade dos animais (GRUBMAN; BAXT, 2004, p. 474 $-475)$.

O período de incubação da febre aftosa varia entre um e catorze dias, prevalecendo períodos curtos (até três dias), em especial em suínos. O vírus se liga aos receptores presentes no epitélio e é internalizado por endocitose. A principal proteína da cápside viral envolvida nesse processo é a VP1 (ALAM et al., 2013, p. 37). Em seguida, ocorre o primeiro ciclo de replicação, que varia de acordo com a porta de entrada do vírus: na mucosa da via respiratória superior, quando a transmissão é aerógena, como predomina em bovinos; ou na região faríngea ou mucosa gastrintestinal, quando a infecção é por via oral, como costuma ocorrer com suínos. Em seguida, as células adjacentes são infectadas, e o vírus passa ao sangue e aos vasos linfáticos, atingindo gânglios e glândulas. Após a viremia, o vírus chega ao epitélio oral, nasal, das patas, do rúmen e do úbere. Ali se replica, sendo que, antes do aparecimento dos primeiros sinais clínicos - febre e formação de vesículas - já está presente em quase todas as secreções do hospedeiro, podendo infectar outros animais susceptíveis (SUTMOLLER et al., 2003, p. 102). 
As vias de transmissão mais importantes da febre aftosa incluem o contato direto com o conteúdo da vesícula, secreções e excreções; a transmissão por aerossóis; e o contato indireto, por meio de fômites e de produtos e subprodutos contaminados. Leite, saliva, urina, sêmen e fezes possuem altas concentrações de vírus, que podem contaminar o ambiente ou infectar outros animais. A via de entrada da infecção geralmente é respiratória, mas a forma oral também pode ter relevância, especialmente em suínos (STENFELDT et al., 2016, p. 2-3). Essa espécie também é conhecida como amplificadora da doença, uma vez que elimina, em suas secreções, grandes quantidades de vírus (PACHECO; MASON, 2010, p. 134).

A viremia dura em torno de cinco dias, e o período de transmissibilidade se estende até duas semanas. Após esse período, apenas animais portadores são capazes de transmitir o vírus, que se mantém na região esofágico-faríngeo por até 24 meses em bovinos e 6 meses em pequenos ruminantes (PINTO, 2012, p. 2). As figuras 1 e 2, a seguir, resumem a dinâmica da patogenia da febre aftosa:

\begin{tabular}{|c|c|}
\hline \multicolumn{2}{|l|}{ Patogenia da Febre Aftosa } \\
\hline $\begin{array}{l}\text { a - Inalação do vírus } \\
\text { b - Infecção de células na cavidade nasal, faringe e esôfago } \\
\text { c - Replicação do vírus e disseminação para células } \\
\text { adjacentes } \\
\text { d - Passagem do vírus a vasos sanguíneos e linfáticos } \\
\text { e - Infecção de nódulos linfáticos e outras glândulas } \\
\text { f - Infecção de células da cavidade oral, patas, úbere e rúmen }\end{array}$ & $\begin{array}{c}24-72 \mathrm{~h} \\
\text { (1 a } 3 \text { dias) }\end{array}$ \\
\hline $\begin{array}{l}\text { g - Começo da febre } \\
\text { h - Aparecimento de vesículas na cavidade oral, patas, úbere } \\
\text { e rúmen } \\
\text { i - Salivação e descarga nasal e claudicação }\end{array}$ & $\begin{array}{c}72-96 h \\
\text { (3 a } 4 \text { dias) }\end{array}$ \\
\hline $\begin{array}{l}\text { j - Ruptura de vesículas e intensificação de sintomas } \\
\text { k - Final da febre } \\
\text { l - Final da viremia e começo da produção de anticorpos }\end{array}$ & $\begin{array}{c}120 \mathrm{~h} \\
(5 \text { dias })\end{array}$ \\
\hline $\begin{array}{l}\text { m - Diminuição do título de vírus em vários tecidos e } \\
\text { líquidos }\end{array}$ & A partir do $8^{\circ}$ dia \\
\hline n - Cura de lesões e o animal começa a comer & A partir do $10^{\circ}$ dia \\
\hline $\begin{array}{l}\text { o - Desaparecimento gradual do vírus de tecidos e líquidos } \\
\text { p - Aumento da produção de anticorpos }\end{array}$ & A partir do $15^{\circ}$ dia \\
\hline $\begin{array}{l}\text { q - Cura completa } \\
\text { (O vírus pode persistir na região nasofaringeana por tempo } \\
\text { de } 6 \text { a } 24 \text { meses em bovinos e de } 4 \text { a } 6 \text { meses em pequenos } \\
\text { ruminantes, segundo fichas técnicas da OIE) }\end{array}$ & 15 dias \\
\hline
\end{tabular}

Figura 1: Patogenia da febre aftosa em bovinos (Fonte: https://www.paho.org/panaftosa/ - Links: Enfermidades Vesiculares/Febre Aftosa/Diagnósticos, acessado em julho de 2016). 


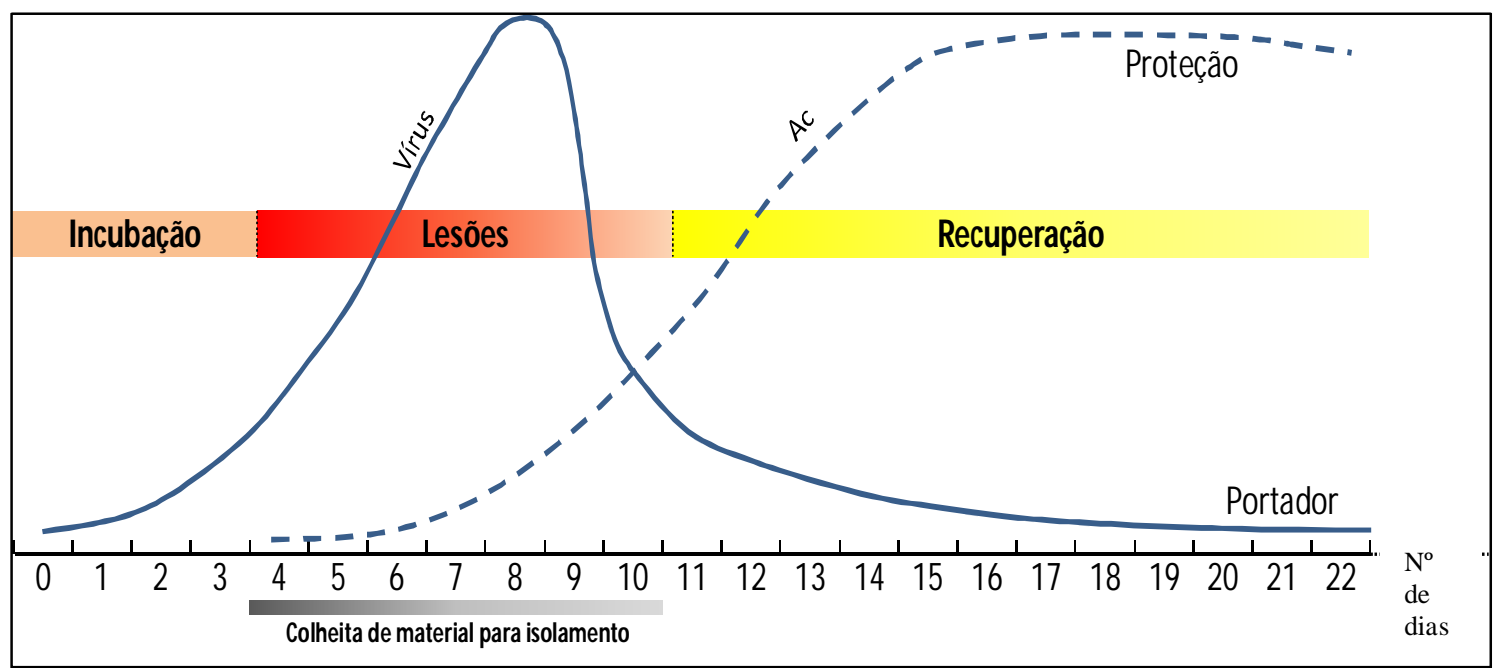

Figura 2: Evolução teórica da febre aftosa, em dias correntes, em um bovino infectado (Fonte: adaptado do documento Série de Manuais Didáticos, n² 2, Panaftosa, 1978, p. 37).

A febre aftosa já foi registrada em diversos países. Foi erradicada com sucesso nos Estados Unidos, Canadá, México, América Central e Austrália, entre outros (OIE, 2018). Os países da Europa Ocidental também levaram a cabo programas bem-sucedidos de erradicação, embora tenha ocorrido uma reintrodução do vírus na Grã-Bretanha, em 2007. Situação semelhante ocorreu no Japão, país livre da doença, onde ocorreu um foco deflagrado em 2010. Ambos os países restituíram sua condição perante a Organização Mundial de Saúde Animal (OIE) após a erradicação dos surtos e a comprovação da ausência de circulação viral.

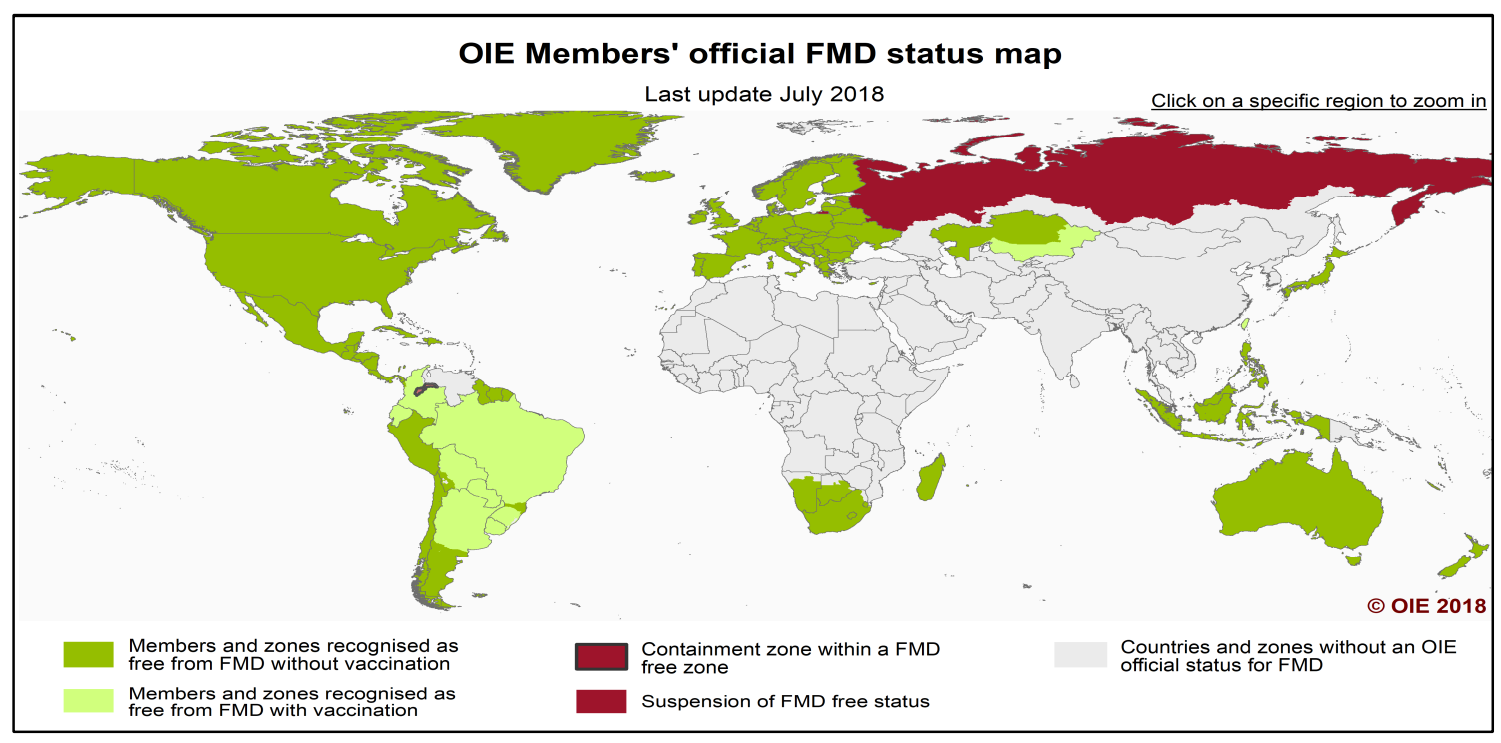

Figura 3: mapa dos países segundo status sanitário em relação à febre aftosa (Fonte: http://www.oie.int/en/animal-health-in-the-world/official-disease-status/fmd/en-fmd-carte/, acessado em 01/08/2018) 
Na América do Sul, a distribuição geográfica da febre aftosa sofreu drásticas mudanças nas últimas décadas. Diversos países têm apresentado significativos avanços em seus programas de controle e erradicação, com expansão de zonas livres, com ou sem vacinação, reconhecidas pela OIE. Atualmente, grande parte do território sul-americano é declarado livre da doença, conforme é demonstrado no mapa abaixo:

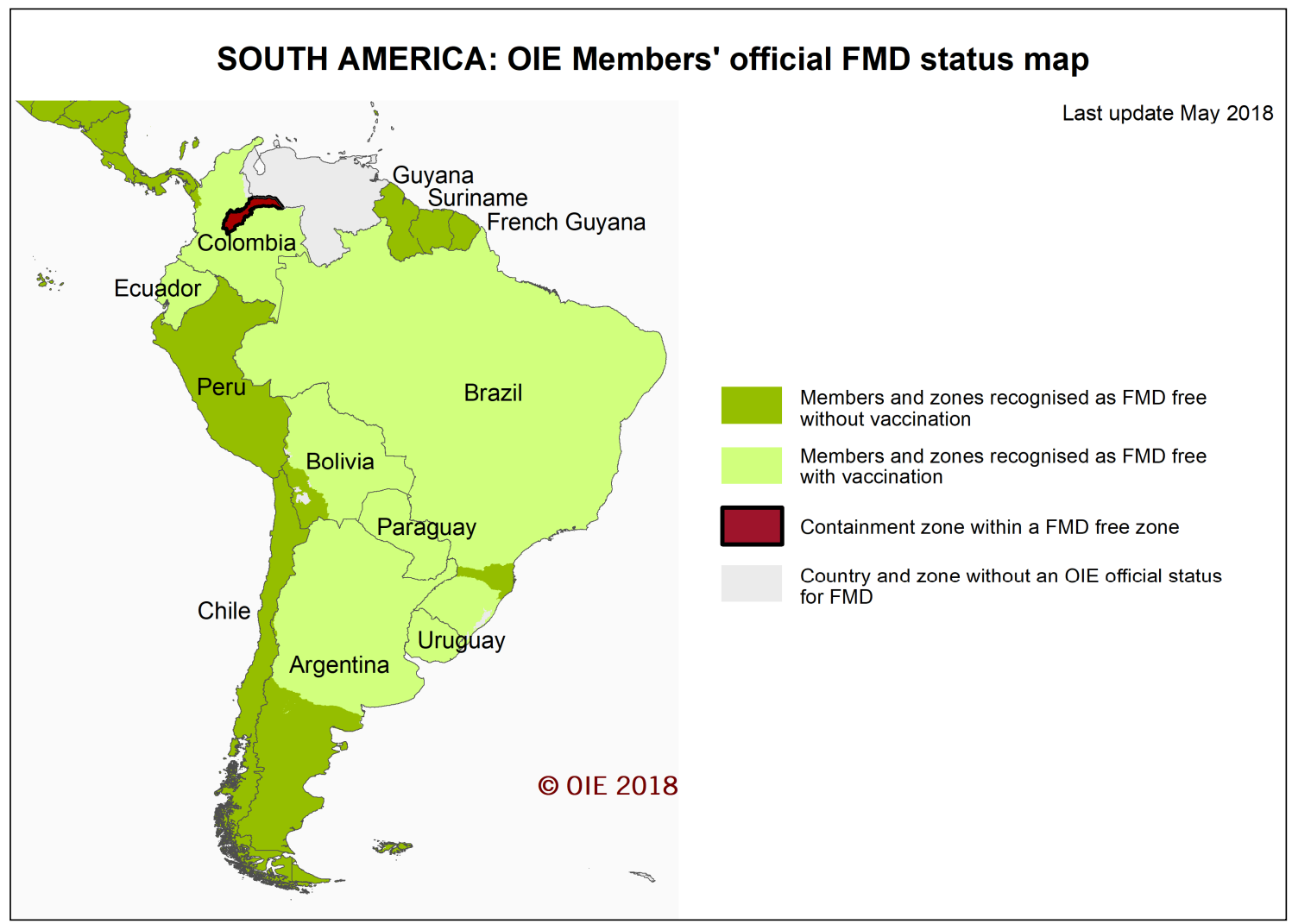

Figura 4: status sanitário dos países da América do Sul em relação à febre aftosa (Fonte: http://www.oie.int/fileadmin/Home/js/images/fmd/FMD_SouthAmerica_ENG.png, acessado em $01 / 06 / 2018)$

Destaca-se que todo o Brasil foi reconhecido pela OIE como livre de febre aftosa com vacinação pela OIE, conquista alcançada em janeiro de 2018, sendo que os três últimos Estados - Roraima, Amapá e Amazonas foram reconhecidos em 2017 pelo MAPA como zona livre de Febre Aftosa com vacinação, e o reconhecimento oficial mundial dessa condição sanitária foi na reunião anual da OIE, em maio de 2018, em Paris (BRASIL, 2017; OIE, 2018).

No Brasil, está implementado desde 1992 o Programa Nacional de Erradicação de Febre Aftosa (PNEFA), que fixa as diretrizes para a vigilância e a erradicação da doença em território nacional. As estratégias implementadas pelo PNEFA incluem a estruturação 
de ações de vigilância epidemiológica, o controle do trânsito de animais susceptíveis, a declaração de zonas livres da doença e a vacinação massal de bovinos e bubalinos (BRASIL, 2007).

A escolha quanto a quais espécies vacinar é uma decisão estratégica, que varia de acordo com o planejamento adotado pela autoridade sanitária oficial. Os suídeos, por exemplo, são altamente sensíveis ao vírus, mas estudos têm sugerido que sua resposta imunológica frente à vacinação é pouco satisfatória. LUCAM e FÉDIDA (1958, p. 621) testaram vacinas monovalentes em suínos, em doses que variaram de 1,4 a $64 \mathrm{~mL}$. Segundo esse estudo, a dose necessária para um índice de $50 \%$ de proteção contra a generalização podal seria de $51 \mathrm{~mL}$. Esse volume corresponde a 30 vezes a dose usada, considerando o mesmo tipo de vacina, para proteger $100 \%$ dos bovinos - uma quantidade inviável para se aplicar por via intramuscular em suínos.

Mais tarde, substituindo-se o hidróxido de alumínio por adjuvantes oleosos, foi possível produzir vacinas mais eficientes (KAHN et al, 2002, p. 350). Já em 1976, uma vacina produzida a partir do sorotipo O1, com uso de adjuvante de Freund incompleto, mostrou-se viável para utilização em suínos. A longevidade da proteção, porém, provouse ainda bastante variável - aos 90 dias pós vacinação, de 33 a 100\% dos animais estavam protegidos contra desafios de inoculação viral (MCKERCHER; BACHRACH, 1976, p. 67). Essa variação de resposta em animais mantidos e vacinados sob as mesmas condições mostra o quanto pode ser difícil predizer a resposta imunitária de suínos frente às vacinas contra a febre aftosa, em perspectiva de rebanho. Ainda hoje, embora existam, fora do Brasil, vacinas contra febre aftosa elaboradas para uso em suínos, desenvolver imunidade adequada nessa espécie, por meio da vacinação, é considerada um desafio (PEREZ; WILLEBERG, 2017, p. 133).

Deve-se levar em conta também o papel epidemiológico do suíno na transmissão da febre aftosa e os sistemas de produção adotados no Brasil. Os suínos têm grande capacidade de replicar o vírus da febre aftosa, eliminando-o em altas concentrações. Por isso, são considerados multiplicadores da doença (PACHECO; MASON, 2010, p. 134). Por outro lado, embora mais sensível, é uma espécie menos susceptível - ou seja, é necessária uma maior carga viral para a infecção inicial; ainda que, uma vez a infecção estabelecida, os sinais clínicos tendam a ser mais severos (PITUCO, 2012, p.5). Também é sabido que, no país, os suínos comerciais são criados em sistemas de alta biosseguridade 
- o que é especialmente verdadeiro em granjas de reprodução. Portanto, pode-se concluir que a vacinação massal de suínos não seria tecnicamente conveniente ao país. Em relação a criações de fundo de quintal, é fundamental que o Serviço Veterinário Oficial (SVO) invista em educação sanitária. Deve-se esclarecer aos produtores a dinâmica da doença nos rebanhos suínos, ressaltando-se que, nessa espécie, a via digestiva é a principal porta de entrada do vírus, ao contrário do que ocorre com bovinos. Assim, os cuidados com a origem e a qualidade da alimentação fornecida aos animais tem papel fundamental na prevenção da doença (ZANELLA et al., 2016; PITUCO, 2012, p.5).

Ovinos e caprinos, ao contrário dos suínos, tendem a apresentar uma resposta imunológica bastante satisfatória frente à vacinação. Em países como a Grécia, com uma população de ovinos e caprinos significativa - que superava em mais de dez vezes a população bovina, no ano de 2000 - a vacinação massal dessas espécies foi considerada ponto fundamental de controle da doença, quando da ocorrência de um foco naquele ano (APHIS, 2000, p. 1-2). Pequenos ruminantes tendem a exibir sinais clínicos mais brandos que bovinos e suínos, mas podem representar excelentes sentinelas sorológicos quando não vacinados, razão pela qual o Brasil optou por proibir a vacinação dessas espécies (BRASIL, 2007, p. 7).

Para bovinos e bubalinos, a vacinação é obrigatória em todo o Brasil, exceto no Estado de Santa Catarina (BRASIL, 2007, p. 5). Na maioria das Unidades Federativas, a vacinação é realizada duas vezes ao ano. Em São Paulo, até 2017, era obrigatória a vacinação de animais de até 24 meses em maio, e de todo o rebanho em novembro. Porém, por solicitação dos pecuaristas - que entendiam que a vacinação de fêmeas em idade reprodutiva em novembro comprometia a eficiência da estação de monta - o calendário foi invertido. A partir de 2018, os animais de até 24 meses passaram a ser vacinados em novembro, enquanto a etapa que envolve todo o rebanho foi passada para maio. De fato, FERREIRA (2015, p. 51) demonstrou que a vacinação contra febre aftosa, durante a gestação precoce, aumenta em quatro vezes a incidência de perda embrionária, quando comparado com a aplicação da vacina sete ou mais dias antes da inseminação.

Um dos pontos chave para que a estratégia de vacinação massal tenha sucesso é a manutenção de altos índices de anticorpos vacinais circulantes na população alvo. Tais índices podem ser mensurados por meio de técnicas sorológicas, como o ELISA de Competição em Fase Líquida - ELISA-CFL, uma das técnicas preconizadas pela OIE 
para a detecção de anticorpos estruturais contra o vírus da febre aftosa (OIE, 2015). Na última década, o Brasil tem feito estudos periódicos para avaliar o nível de proteção imunitária de seu rebanho com uso do ELISA-CFL. 


\section{OBJETIVOS}

Os objetivos gerais do presente trabalho foram:

- Avaliar o resultado das ações do Programa de Erradicação da Febre Aftosa no Estado de São Paulo;

- Subsidiar o fortalecimento da estrutura dos programas sanitários e dos sistemas de atenção veterinária do Estado de São Paulo;

- Fomentar a cooperação técnico-científica entre Instituições de Pesquisa, MAPA e Coordenadoria de Defesa Agropecuária do Estado de São Paulo.

Os objetivos específicos do presente trabalho foram:

- Avaliar a condição imunitária do rebanho bovino do Estado de São Paulo, vacinado sistematicamente contra o vírus da febre aftosa;

- Contribuir com a realização das ações previstas no Plano Nacional de Erradicação da Febre Aftosa. 


\section{REVISÃO DE LITERATURA}

O uso massal da vacinação em animais susceptíveis é uma estratégia fundamental para a redução da prevalência da febre aftosa, no intuito de se passar à erradicação (SAMARA; BUZINARO; CARVALHO, 2004, p. 375). Juntamente com o controle de trânsito de animais e produtos e o abate sistemático de animais infectados, tem formado a base da maioria dos programas de erradicação de febre aftosa conhecidos no mundo (GRUBMAN, 2006, p. 341). Até a década de 1990, o Brasil utilizava basicamente vacinas de adjuvantes aquosos, à base de hidróxido de alumínio, cuja eficácia é bastante inferior às fabricadas com adjuvante oleoso (CUNLIFFE; GRAVES, 1963, p. 194). Em 1968, o Centro Panamericano de Febre Aftosa (PANAFTOSA) iniciou o estudo de vacinas oleosas, com o uso do adjuvante VA-AO (NADER et al., 1992, p. 785). Logo se comprovou que o uso dessa nova tecnologia permitia a produção de títulos de anticorpos contra febre aftosa mais altos e mais duradouros, o que levou à massificação da produção de vacinas oleosas.

A vacina é obtida a partir de uma suspensão estável do vírus inativado em adjuvante oleoso, composto geralmente por óleo mineral e um emulsificante (NADER et al., 1992, p. 785). O adjuvante estimula a proliferação de linfócitos $\mathrm{T}$, a produção de linfocinas e a resposta humoral ao antígeno. No sítio de depósito do antígeno, se forma um granuloma e, em consequência, há um estímulo específico para a resposta imune retardada, o que explica a maior longevidade da produção de anticorpos em animais vacinados (NADER et al., 1992, p. 785). A partir de 1996, com o uso exclusivo de vacinas oleosas, o Programa Nacional de Erradicação de Febre Aftosa deu um salto qualitativo, evidenciado pela acentuada queda do número de focos desde então (LYRA; SILVA, 2004, p. 571).

A acentuada queda no número de focos de febre aftosa a partir das décadas de 1980 e 1990 deveu-se, além da adoção da vacina oleosa, do avanço das medidas oficiais de controle da doença, como a melhoria do cadastro de propriedades rurais, estruturação dos serviços oficiais, controle do trânsito de animais e produtos e caracterização dos ecossistemas de febre aftosa (PITUCO, 2013, p.5). O sucesso do PNEFA pode ser constatado, na prática, pela completa erradicação da doença no país, conforme se observa no gráfico a seguir: 


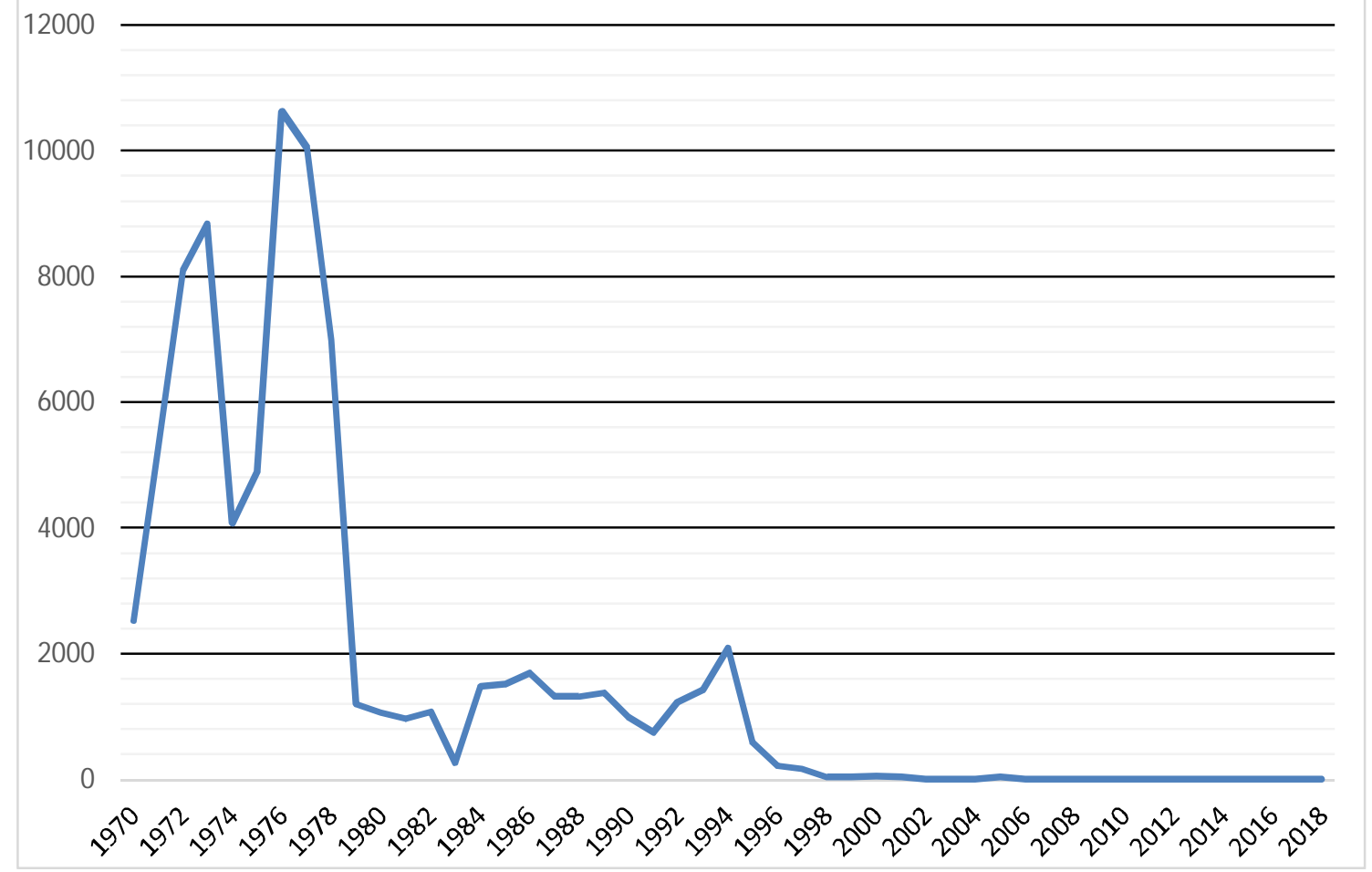

Gráfico 1: Número de focos de febre aftosa no Brasil, de 1970 a 2018 (adaptado de LYRA; SILVA, 2004, p. 572).

No Brasil, a responsabilidade pela aplicação da vacina cabe aos produtores rurais. No entanto, as estratégias de vacinação são definidas em conjunto pelo MAPA e pelos Serviços Veterinários Estaduais, com base na situação epidemiológica e nas características geográficas e agroprodutivas de cada Unidade da Federação (BRASIL, 2007, p. 3). São oficialmente reconhecidas as seguintes estratégias de vacinação contra a febre aftosa (BRASIL, 2007, p. 6):

1. Vacinação semestral de todos os animais, em etapas com duração de 30 dias;

2. Vacinação semestral de animais com até 24 (vinte e quatro) meses de idade e anual para animais com mais de 24 meses de idade, com realização ou não de etapa de reforço para animais com até 12 (doze) meses de idade, em etapas com duração de 30 (trinta) dias;

3. Vacinação anual de todos os animais, em etapas de 45 a 60 dias, em regiões onde as características geográficas possibilitam o manejo das explorações pecuárias apenas durante período limitado do ano. 
Cabem nesse último item as regiões reconhecidas pelo MAPA como de difícil manejo, o que hoje inclui o Estado do Amapá, o bioma do Pantanal (Mato Grosso e Mato Grosso do Sul), o arquipélago de Marajó e os municípios de Faro e Terra Santa (Pará) e a Ilha do Bananal (Tocantins). É importante ressaltar que, embora essas estratégias sejam reconhecidas, nem todas necessariamente, são utilizadas na prática. Atualmente, devido ao avanço do PNEFA e à erradicação da doença em território nacional, não mais se utiliza o esquema de vacinação mais conservador - a vacinação semestral de todo o rebanho (MAPA, 2018, p. 4). O calendário de vacinação atualmente vigente está representado nas figuras a seguir:

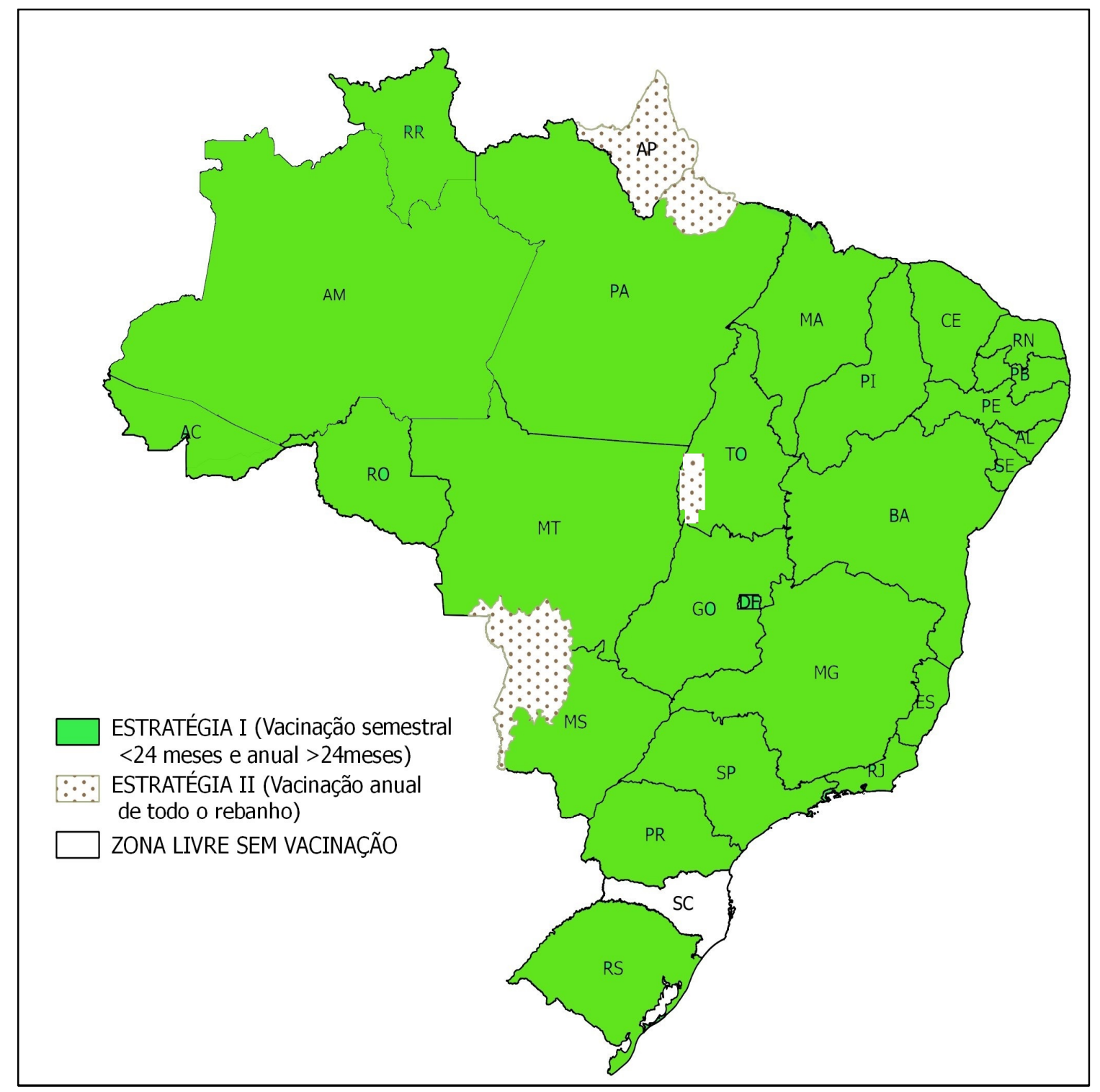

Figura 5: Mapa das estratégias de vacinação contra febre aftosa adotadas no Brasil (Fonte: www.agricultura.gov.br - Links: Sanidade Animal e Vegetal/Saúde Animal/Programas de Saúde Animal/ Febre Aftosa/Calendário de Vacinação, acessado em setembro de 2018). 


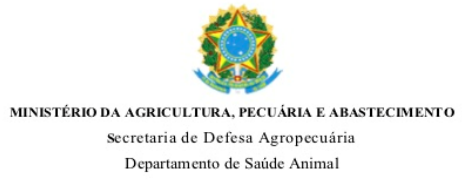

Calendário nacional de vacinação dos bovinos e bubalinos contra a febre aftosa 2018

\begin{tabular}{|c|c|c|c|c|c|c|c|c|c|c|c|c|}
\hline UF & JAN & FEV & MAR & ABR & MAI & JUN & JUL & AGO & SET & OUT & NOV & DEZ \\
\hline ACRE & & & & & 3 & & & & & & 1 & \\
\hline ALAGOAS & & & & & 1 & & & & & & 3 & \\
\hline AMAPÁ & & & & & & & & & 4 & 4 & 4 & \\
\hline AMAZONAS (a) & & & 1 & 1 & 1 & & 3 & 3 & & 3 & 3 & \\
\hline BAHIA & & & & & 1 & & & & & & 3 & \\
\hline CEARÁ & & & & & 1 & & & & & & 3 & \\
\hline DISTRITO FEDERAL & & & & & 1 & & & & & & 3 & \\
\hline ESPIRITO SANTO & & & & & 3 & & & & & & 1 & \\
\hline GOIÁs & & & & & 1 & & & & & & 3 & \\
\hline MARANHÃO & & & & & 1 & & & & & & 3 & \\
\hline MATO GROSSO (b) & & & & & 1 & & & & & & 3 & 4 \\
\hline MATO GROSSO DO SUL (c) & & & & & 1 & 4 & & & & & 3 & 4 \\
\hline MINAS GERAIS & & & & & 1 & & & & & & 3 & \\
\hline PARÁ (d) & & & 1 & 1 & 1 & & 3 & 3 & & & 3 & \\
\hline РАКА W & & & & & & & & 4 & 4 & 4 & 3 & \\
\hline PARAÍBA & & & & & 1 & & & & & & 3 & \\
\hline PARANÁ & & & & & 3 & & & & & & 1 & \\
\hline PERNAMBUCO & & & & & 1 & & & & & & 3 & \\
\hline PIAUÍ & & & & & 1 & & & & & & 3 & \\
\hline RIO DE JANEIRO & & & & & 1 & & & & & & 3 & \\
\hline RIO GRANDE DO NORTE & & & & & 1 & & & & & & 3 & \\
\hline RIO GRANDE DO SUL & & & & & 1 & & & & & & 3 & \\
\hline RONDÔNIA & & & & & & & & & & & & \\
\hline RORAIMA (e) & & & & 1 & & & & & & 3 & & \\
\hline & & & & 1 & 1 & & & & & 3 & 1 & \\
\hline SÃo PAULO & & & & & 1 & & & & & & 3 & \\
\hline SERGIPE & & & & & 1 & & & & & & 3 & \\
\hline TOCANTINS & & & & & 1 & & & 4 & 4 & & 3 & \\
\hline
\end{tabular}

Atualizado em 31/08/2018

Legenda:

Estratégias de vacinação autorizadas pelo MAPA-IN 44/2007.
\begin{tabular}{|c|l|}
\hline 1 & Vacinação de todo o rebanho bovino e bubalino. \\
\cline { 1 - 1 } & $\begin{array}{l}\text { Vacinação de animais com menos de } 12 \text { meses. } \\
\text { Vacinação de animais com idade até } 24 \text { meses. }\end{array}$ \\
\cline { 1 - 1 } 3 & Vacinação anual de todo o rebanho bovino e bubalino. \\
\hline 4
\end{tabular}

(a) A vacinação nos períodos de 15/03 a 30/04 e de 15/07 a 30/08 ocorre em 41 municípios que compõem as margens do Rio Amazonas. Os municípios de Guajará e Boca do Acre seguem o calendário do estado do Acre. As propriedades do sul de Canutama e Lábrea seguem o calendário

(b) Nas propriedades do Pantanal, a vacinação é realizada em todo rebanho bovino e bubalino no período de 01/11 a 15/12.

(c) Nas propriedades do Pantanal, os produtores devem vacinar todo o rebanho, optando pelos períodos de 01/05 a 15/06 ou 01/11 a 15/12.

(d) Nos municípios de Faro e Terra Santa os bovinos e búfalos são vacinados nos períodos de 15/3 a 30/4 e de 15/7 a 30/8. No Arquipélago do Marajó, todo o rebanho bovino e bubalino é vacinado de $15 / 08$ a $15 / 10$.

(e) Nas reservas indígenas "Raposa Serra do Sol" e "São Marcos", onde são vacinados os bovinos e búfalos de todas as faixas etárias, a vacinação se estende até os dias $15 / 5$ e $15 / 11$.

(f) Na Ilha do Bananal, são vacinados todos os bovinos e búfalos no período de 01/08 a 15/09.

Figura 6: Calendário nacional de vacinação de bovinos e bubalinos contra a febre aftosa (Fonte: www.agricultura.gov.br - Links: Sanidade Animal e Vegetal/Saúde Animal/Programas de Saúde Animal/ Febre Aftosa/Calendário de Vacinação, acessado em setembro de 2018). 
As estratégias atualmente adotadas, fiscalizadas pelo SVO, têm permitido níveis de coberturas vacinais acima de $80 \%$, a taxa mínima preconizada pelo MAPA (MAPA, 2007, p. 4). Dada a impossibilidade de o SVO acompanhar $100 \%$ das vacinações, tal índice é calculado segundo as declarações de vacinação dos produtores rurais. De fato, o índice nacional de animais vacinados vem se aproximando de $100 \%$ nos últimos anos, conforme se verifica na figura a seguir:

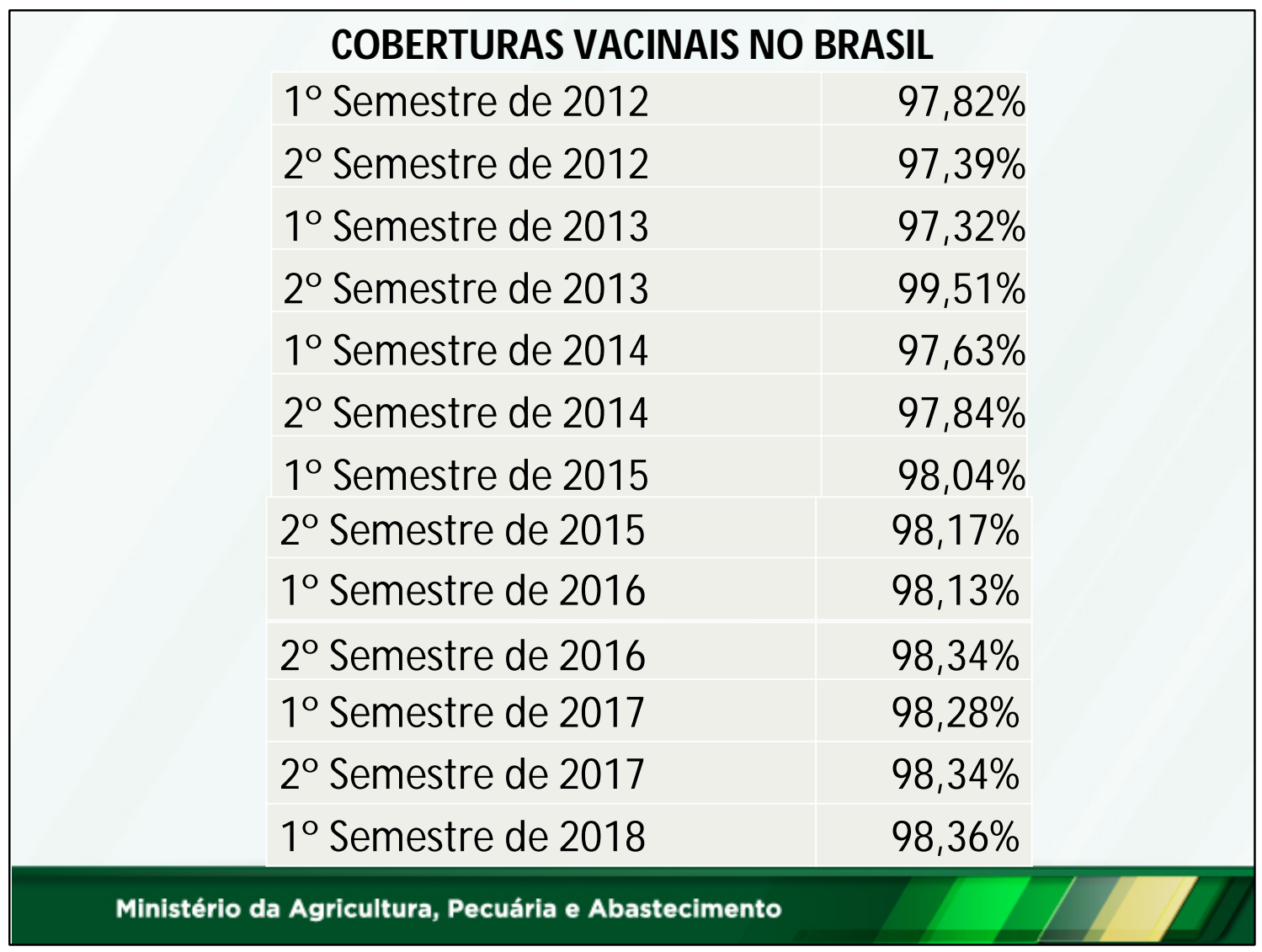

Figura 7: Índices nacionais de coberturas vacinais de bovinos e bubalinos contra a febre aftosa (Fonte: www.agricultura.gov.br - Links: Sanidade Animal e Vegetal/Saúde Animal/Programas de Saúde Animal/ Febre Aftosa/Campanhas de Vacinação, acessado em setembro de 2018).

Embora a média nacional de cobertura vacinal seja bastante satisfatória, nem todas as Unidades Federativas se encontram no mesmo estágio de avanço. $\mathrm{O}$ encerramento da última campanha de vacinação, ocorrida em maio de 2018, demonstrou que os índices de cobertura vacinal variaram de $86,25 \%$ a $99,96 \%$ nos diferentes Estados, tendo São Paulo fechado sua campanha com excelentes $99,42 \%$ (Figura 8 ). 


\begin{tabular}{|c|c|c|c|c|}
\hline \multicolumn{5}{|c|}{$\begin{array}{c}\text { Ministério da Agricultura, Pecuária e Abastecimento } \\
\text { Secretaria de Defesa Agropecuária } \\
\text { Departamento de. Saíde Animal }\end{array}$} \\
\hline \multicolumn{5}{|c|}{ Resultados da vacinação contra Febre Aftosa do $1^{\circ}$ semestre de 2018 - Brasil } \\
\hline UF & $\begin{array}{l}\text { Bovinos e } \\
\text { Bubalinos } \\
\text { existentes }\end{array}$ & $\begin{array}{l}\text { Bovinos e Bubalinos } \\
\text { envolvidos na etapa }\end{array}$ & $\begin{array}{l}\text { Bovinos e bubalinos } \\
\text { vacinados na etapa }\end{array}$ & $\begin{array}{c}\text { Cobertura Vacinal } \\
(\%)\end{array}$ \\
\hline Acre & 3.128 .728 & 1.313 .124 & 1.299 .682 & 98,98 \\
\hline Alagoas & 1.101 .495 & 1.080 .712 & 1.042 .999 & 96,51 \\
\hline Amapá & 340.227 & não se aplica & não se aplica & não se aplica \\
\hline Amazonas & 1.385 .714 & 1.135 .909 & 1.108 .729 & 97,61 \\
\hline Bahia & 9.816 .451 & 9.775 .735 & 9.145 .667 & 93,55 \\
\hline Ceará & 2.531 .592 & 2.519 .529 & 2.305 .000 & 91,49 \\
\hline Distrito Federal & 94.037 & 93.121 & 91.334 & 98,08 \\
\hline Espirito Santo & 1.955 .712 & 602.016 & 594.434 & 98,74 \\
\hline Goiás & 22.682 .185 & 22.478 .802 & 22.354 .373 & 99,45 \\
\hline Maranhão & 8.005 .623 & 7.966 .432 & 7.785 .488 & 97,73 \\
\hline Mato Grosso & 30.089 .432 & 29.635 .561 & 29.568 .091 & 99,77 \\
\hline Mato Grosso do Sul & 21.196 .597 & 20.611 .450 & 20.449 .640 & 99,21 \\
\hline Minas Gerais & 23.309 .428 & 23.149 .272 & 22.554 .440 & 97,43 \\
\hline Pará (Arquipélago do Marajó) & 623.292 & não se aplica & não se aplica & não se aplica \\
\hline Pará (demais municípios) & 20.656 .192 & 20.589 .832 & 20.386 .216 & 99,01 \\
\hline Paraiba & 1.234 .841 & 1.231 .642 & 1.062 .247 & 86,25 \\
\hline Paraná & 9.214 .653 & 4.014 .714 & 3.970 .705 & 98,90 \\
\hline Pernambuco & 1.798 .761 & 1.787 .330 & 1.698 .395 & 95,02 \\
\hline Piaui & 1.652 .775 & 1.643 .705 & 1.484 .889 & 90,34 \\
\hline Rio de Janeiro & 2.555 .857 & 2.552 .386 & 2.269 .985 & 88,94 \\
\hline Rio Grande do Norte & 893.814 & 893.307 & 865.287 & 96,86 \\
\hline Rio Grande do Sul & 13.260 .312 & 13.260 .312 & 13.126 .602 & 98,99 \\
\hline Rondônia & 13.830 .333 & 13.649 .767 & 13.644 .513 & 99,96 \\
\hline Roraima & 808.503 & 807.084 & 800.421 & 99,17 \\
\hline Santa Catarina & 4.610 .363 & não se aplica & não se aplica & não se aplica \\
\hline São Paulo & 11.042 .022 & 10.935 .386 & 10.871 .421 & 99,42 \\
\hline Sergipe & 1.014 .999 & 1.014 .429 & 940.706 & 92,73 \\
\hline Tocantins (exceto llha do Bananal) & 8.545 .134 & 8.495 .251 & 8.458 .198 & 99,56 \\
\hline Tocantins (Ilha do Bananal) & 114.795 & não se aplica & não se aplica & não se aplica \\
\hline Total & 217.493 .867 & 201.236 .808 & 197.879.462 & 98,33 \\
\hline \multicolumn{5}{|c|}{ Fonte: Serviços Veterinários Estaduais } \\
\hline \multicolumn{5}{|l|}{ Data de atualização: 28/08/2018 } \\
\hline \multicolumn{5}{|c|}{$\begin{array}{l}\text { Coordenação Geral de Sanidade Animal } \\
\text { Coordenação de Animais Terrestres } \\
\text { isão de Febre Aftosa e Outras Doenças Vesiculares }\end{array}$} \\
\hline
\end{tabular}

Figura 8: Resultados da vacinação contra Febre Aftosa do primeiro semestre de 2018 - Brasil (Fonte: www.agricultura.gov.br - Links: Sanidade Animal e Vegetal/Saúde Animal/Programas de Saúde Animal/ Febre Aftosa/Campanhas de Vacinação, acessado em setembro de 2018).

Altos índices de cobertura vacinal não garantem, por si só, altos índices de anticorpos no soro sanguíneo de animais vacinados. Embora seja um importante indicador, é necessário avaliar a efetiva resposta dos animais, ou seja, a proteção contra o vírus da 
febre aftosa. Além da sempre existente possibilidade da declaração do produtor não ser acompanhada da execução da vacinação, outros fatores devem ser considerados para se avaliar a eficiência do uso dessa ferramenta. A importância da manutenção da cadeia do frio, não apenas para a conservação da vacina contra a febre aftosa, mas de qualquer vacina, já foi bem estabelecida (ARANDA; MORAES, 2006, p.172). Atualmente, o MAPA preconiza que as vacinas contra febre aftosa sejam mantidas em temperaturas de 2 a $8^{\circ} \mathrm{C}$ (MAPA, 2005, p.2). Fora dessa faixa de temperatura, ficam comprometidas as características imunogênicas da vacina, razão pela qual a cadeia de frio deve ser mantida em todas as etapas de armazenamento, distribuição, transporte e manuseio (ARANDA; MORAES, 2006, p.173). Falhas no cumprimento das recomendações para conservação de vacinas são mais frequentes que o desejável, não apenas em países em desenvolvimento como nos desenvolvidos, razão pela qual há necessidade de supervisão permanente, adequação de equipamentos e capacitação de recursos humanos por parte das autoridades oficiais (ARANDA; MORAES, 2006, p.173).

Outros aspectos são igualmente importantes para se atingir a adequada imunização do rebanho. A dose inoculada, o local e a via de administração influenciam diretamente na resposta imune pós-vacinação (SAMARA; BUZINARO; CARVALHO, 2004, p. 375). Estudos apontam que rebanhos vacinados sob estrito acompanhamento técnico podem apresentar até taxas de resposta imune até $40 \%$ superiores a rebanhos sem acompanhamento, utilizando-se vacina de mesma qualidade (SAMARA; BUZINARO; CARVALHO, 2004, p. 377). Portanto, o rígido controle na produção de vacinas, exercido pelos órgãos oficiais, pode ser insuficiente para a obtenção de um resultado final satisfatório nas ações de campo. O MAPA atualmente preconiza a aplicação de $5 \mathrm{~mL}$ da vacina, por via subcutânea ou intramuscular, na região da tábua do pescoço (MAPA, 2005, p.3).

Ademais, a fim de atingirem níveis de proteção adequada, as vacinas devem manter as propriedades antigênicas dos vírus circulantes. Isso pode ser difícil de se obter na prática, devido, sobretudo, à heterogeneidade antigênica entre vírus que circulam simultaneamente a campo. A proteção também pressupõe que as vacinas devam incluir epítopos de células $\mathrm{B}$ e células $\mathrm{T}$ para diferentes sorotipos, de modo a induzir a formação de um amplo repertório de anticorpos neutralizantes - minimizando, assim, a seleção de vírus variantes que surgem durante a replicação (SOBRINO; DOMINGO, 2001, p. 460). As primeiras vacinas polivalentes inativadas de vírus inteiros, tradicionalmente 
empregadas para controle de febre aftosa, conseguiram cumprir esses requisitos apenas de maneira parcial (BACHRACH, 1968, p. 203; SOBRINO; DOMINGO, p. 460). Em 1953, na Holanda, foi utilizada a primeira vacina de que se tem registro para controle da febre aftosa. Ela foi desenvolvida com base no cultivo de vírus em fragmentos de epitélio da língua bovina, seguido de inativação por meios químicos. A vacina foi batizada de "vacina trivalente de tipo Frankel" (BACHRACH, 1968, p. 201).

Mais tarde, a produção em grande escala em suspensões de células de rim de hamsters lactentes (BHK) produziu vacina em quantidade suficiente para uso massal, o que resultou em uma drástica redução dos casos de febre aftosa na Europa no final da década de 1960. Apesar do sucesso da ação, análises posteriores das sequências de nucleotídeos forneceram evidências de que alguns surtos de doenças na Europa na década de 1980 foram causados por vacinas. Especula-se que tais casos tenham sido produzidos em decorrência da inativação insuficiente do vírus, ou devido a escapes das fábricas de vacinas (SOBRINO; DOMINGO, 2001, p. 460).

Atualmente, apesar dos progressos a olhos vistos na área, ainda não se conseguiu produzir vacinas sintéticas eficazes, que não exigem manipulação de vírus vivo. Isso se deu, entre outros fatores, pela baixa eficiência na produção de partículas inteiras não infecciosas, como cápsides vazias ou vírus com deleções genômicas. Além disso, as indústrias por vezes ignoraram a regra de sempre incluir na formulação das vacinas múltiplos epítopos dos sorotipos que circulam a campo. Isso levou à produção de vacinas que conferiam apenas proteção parcial em susceptíveis vacinados. Tais falhas tecnológicas no desenvolvimento de vacinas, somadas às vantagens comerciais de um continente livre de febre aftosa, levaram a União Europeia a adotar uma política de não vacinação em 1991, o que tornou os rebanhos europeus totalmente suscetíveis ao vírus (SOBRINO et al., 2001, p. 12).

Na América do Sul, a política de vacinação massal é mantida até os dias atuais, com exceção de alguns bolsões bem delimitados que compõem zonas livres de febre aftosa sem vacinação (OIE, 2018). O Brasil optou pelo uso da vacina tríplice, composta por amostras inativadas e purificadas de vírus dos subtipos A24 Cruzeiro, O1 Campos e C3 Indaial (BRASIL, 2018, p. 4), ao passo que outros países optam, na atualidade, pelo uso de vacinas bivalentes (A24 Cruzeiro e O1 Campos). A partir de 2019, o Brasil também 
deverá optar por essa última formulação, uma vez que o vírus $C$ é considerado erradicado do continente (BRASIL, 2018, p. 4).

A relação entre resposta vacinal e sua influência sobre o diagnóstico sempre foi tema de estudo na área. Até 2008, quando não havia obrigatoriedade da purificação da vacina (BRASIL, 2008, p.1), era muito difícil distinguir resposta imune vacinal daquela estimulada pela infecção natural. Para entender a relação entre ambos os fatores, é necessário destrinchar a dinâmica da resposta imune e a composição proteica dos anticorpos. O genoma do vírus da febre aftosa, composto por uma fita simples de RNA, contém apenas uma fase de leitura aberta (ORF - Open Reading Frame), que dá início à síntese de uma poliproteína posteriormente processada por proteinases virais em quatro produtos primários de clivagem (BOTTON, 2005, p. 6):

1. Lpro, que codifica una protease viral,

2. P1-2A, que codifica as quatro proteínas capsidais do vírus: VP1, VP2, VP3 e VP4;

3. P2, que codifica diversas proteínas não capsidais, envolvidas na replicação do RNA e na maturação viral;

4. P3, que codifica diversas proteínas não capsidais, envolvidas na replicação do RNA e na maturação viral.

As quatro Proteínas Capsidais (PC) revestem o RNA viral arranjadas em doze pentâmeros, totalizando sessenta cópias de cada proteína. São estas estruturas responsáveis pela resposta imune primária dos animais infectados. Já as Proteínas não Capsidais (PNC) estão envolvidas com múltiplas funções necessárias para a replicação do RNA genômico e formação de partículas nas células infectadas (MONDRAGÓN; VERA; RESTREPO, 2006, p. 374).

As proteínas estruturais constituem os vírions 146S, subdivididos em diversas unidades, que incluem clusters pentaméricos de VP1, VP2 e VP3. Atualmente, se aceita que a imunogenicidade das partículas 146S é a mais importante na indução da resposta imune. Foram realizados vários estudos no sentido de se correlacionar a carga do antígeno $146 \mathrm{~S}$ à dose vacinal e ao nível de proteção alcançado (MONDRAGÓN; VERA; RESTREPO, 2006, p. 374). DOEL (1999, p. 1770), por exemplo, elucidou que o limite 
crítico da relação partícula/dose era 9,2 mg - ou seja, o incremento da carga viral para valores acima desse, por dose, praticamente não altera a potência da vacina. A importância do vírion 146S na resposta imune levou muitos laboratórios a adotar a integridade dessa partícula como principal parâmetro de qualidade de sua matéria-prima. Entretanto, vale ressaltar que a partícula 146S, mesmo íntegra, pode conter proteínas VP1 parcialmente degradadas por ação de proteases, o que, via de regra, limita a capacidade do vírion de induzir a produção de anticorpos neutralizantes (MONDRAGÓN; VERA; RESTREPO, 2006, p. 374).

Durante a infecção, após uma resposta imune inicial contra as PC, o hospedeiro passa, a partir da replicação viral, a também produzir anticorpos contra as PNC. A detecção desse último tipo de anticorpos é a forma preferencial de se distinguir animais não vacinados de vacinados, embora uma pequena proporção de animais vacinados ainda demonstre algum nível de reatividade contra PNC, mesmo após a adoção exclusiva, no país, de vacinas purificadas. As provas para detectar anticorpos anti-PNC, ao contrário das provas para anticorpos anti-PC, não são soro-específicas, podendo detectar qualquer sorotipo que venha a infectar um hospedeiro susceptível (MONDRAGÓN; VERA; RESTREPO, p. 374).

Entre as provas usadas para a detecção anticorpos anti-PNC, aquelas que detectam anticorpos contra o polipeptídeo $3 \mathrm{ABC}$ têm se mostrado mais eficientes. Para o desenvolvimento da técnica, se produziu as PNC a partir de bactérias Escherichia coli recombinantes ou de células de insetos infectados com bacilovírus recombinantes. (MONDRAGÓN; VERA; RESTREPO, 2006, p. 374). A técnica de ELISA 3ABC foi padronizada no continente pelo PANAFTOSA, e vem sendo utilizada no Brasil como teste de triagem para busca de infecção em animais vacinados. Como teste confirmatório, tem-se utilizado a prova Western Blot de Imunoeletrotransferência - EITB, também fornecida pelo PANAFTOSA. O uso desse sistema tem demonstrado uma sensibilidade acumulada em torno de 90\% (MAPA, 2016, p. 4).

Atualmente, as vacinas são obtidas a partir de concentrados de cultivos celulares infectados e inativados quimicamente. Para uso a campo, o ideal é que essas vacinas, devidamente purificadas, induzam a produção apenas de anticorpos anti-PC. No Brasil, desde 2008 é obrigatória a purificação de vacinas contra a febre aftosa (BRASIL, 2008, p. 1). Ainda assim, observa-se pequenos picos de reatividade imune a PNC em estudos 
de circulação viral no qual se utiliza a prova de ELISA 3ABC, especialmente em animais repetidamente vacinados. Entretanto, estudos demonstram que a aplicação repetida de vacinas de alta potência produzidas com antígenos purificados por ultracentrifugação, ultrafiltração, cromatografia ou o uso de moléculas de condensação linear não induzem a formação de anticorpos PNC detectáveis por provas específicas - cenário ideal para distinguir animais vacinados de infectados (MONDRAGÓN; VERA; RESTREPO, 2006, p. 374).

Para a detecção de PC, a prova de eleição utilizada no Brasil é o ensaio de imunoadsorção enzimática de competição em fase líquida (ELISA-CFL). A prova foi desenvolvida em 1985 por McCULLOUGH; CROWTHER; BUTCHER, p. 329-338, no Laboratório de Referência da OIE para Febre Aftosa em Pirbright, UK (WRL). A técnica foi inicialmente aplicada para caracterizar epítopos do vírus da febre aftosa. No ano seguinte, também no WRL, HAMBLIN; BARNETT; CROWTHER, 1986, p. 115-121, adaptaram a prova para medir anticorpos pós-infecção ou vacinais. Posteriormente, vários laboratórios adotaram a metodologia sendo, no PANAFTOSA, adaptada para o estudo de anticorpos vacinais com cepas sul-americanas (VIANNA FILHO et al., 1993, p. 1424).

O teste de ELISA-CFL é uma técnica de baixo custo, rápida, prática e de alta reprodutibilidade. Além disso, o uso de provas in vitro elimina a necessidade de ensaios em animais vivos - o que, além de representar uma preocupação recorrente do ponto de vista de bem-estar animal, minimiza a chance de escape de vírus viáveis no ambiente (ALLENDE, 2001, p. 14).

Além dos reagentes comuns a outras provas de ELISA, o ELISA-CFL exige o uso dos seguintes reagentes específicos: anticorpos de captura, anticorpos detectores e antígenos de prova. Os anticorpos de captura são obtidos a partir da hiperimunização de coelhos, realizada com vírus de febre aftosa inativado e purificado. Os anticorpos detectores são obtidos pela hiperimunização de cobaias, com vírus de febre aftosa adaptados à espécie. Já os antígenos da prova são derivados de sobrenadante de cultivo de células BHK infectadas com vírus da febre aftosa, tipos A24 Cruzeiro, O1 Campos e C3 Indaial. O sobrenadante é clarificado e inativado com etilenimina binária (BEI), sendo posteriormente tratados com 50\% de glicerol estéril (IICA, 2001). Os antígenos são controlados por meio do uso de um painel de anticorpos monoclonais (ALLENDE, 2001, p. 14). 
A prova de ELISA-CFL consiste de uma fase líquida e uma fase sólida. $\mathrm{Na}$ fase líquida, em uma placa auxiliar, o soro estudado é misturado ao antígeno de prova e ao tampão de diluição, na proporção de $50 \mu \mathrm{L}: 40 \mu \mathrm{L}: 40 \mu \mathrm{L}$, em diluições sequencias de base $5\left(1: 2,1: 10,1: 50,1: 250\right.$ e $1: 1.250$ e 1:6.250). Essa mistura é incubada a $37^{\circ} \mathrm{C}$ por uma hora, com agitação durante os primeiros vinte minutos. (IICA, 2001, p. 157). A fase sólida, por sua vez, é preparada em placa de ELISA, com adição de $100 \mu \mathrm{L}$ do anticorpo de captura em cada poço, acompanhado de tampão Carbonato. A mistura é incubada a $4^{\circ} \mathrm{C}$ por dezoito horas (IICA, 2001, p. 157).

A adição da fase líquida à fase sólida se dá pela transferência de $50 \mu \mathrm{L}$ da mistura soro/antígeno da placa auxiliar à placa sensibilizada com anticorpos de captura. A placa sensibilizada é então incubada a $37^{\circ} \mathrm{C}$ por trinta minutos, sendo posteriormente lavada com solução tampão de lavagem. São adicionados, sequencialmente, $50 \mu \mathrm{L}$ do anticorpo de detecção, do conjugado e do substrato, intercalando-se cada adição com uma nova etapa de incubação e de lavagem. Há uma incubação final, a $25^{\circ} \mathrm{C}$ por 15 minutos, e posterior leitura do resultado, em espectrofotômetro com filtro de $492 \mathrm{~nm}$ (IICA, 2001, p. 158).

O MAPA já utilizou a técnica do ELISA-CLF em um estudo anterior, similar ao atual, realizado em 2007, sobre a avaliação da imunidade populacional resultante das campanhas de vacinação contra febre aftosa (MAPA, 2007, p. 11). O estudo foi conduzido na então zona livre de febre aftosa com vacinação, com objetivo de avaliar os índices de cobertura vacinal elaborados pelo serviço veterinário. O trabalho buscou certificar, indiretamente, o índice de cobertura vacinal a partir da estimativa do nível de proteção imunitária prevalente, para as cepas virais presentes na vacina contra a febre aftosa empregada no país. A estimativa de proteção contra o vírus da febre aftosa dessa população animal também permitiu avaliar as estratégias de vacinação empregadas e a eficiência dos controles das campanhas de vacinação contra a doença. Ao mesmo tempo, aproveitou-se a oportunidade para estimar o grau de envolvimento dos produtores e trabalhadores rurais em relação aos temas de interesse do Programa Nacional de Erradicação da Febre Aftosa (PNEFA), especialmente relacionados às atividades de vacinação contra a febre aftosa, ao reconhecimento e notificação de suspeitas de doenças vesiculares e aos requisitos para movimentação de animais. 
A região de estudo envolveu os Estados do Acre (mais dois municípios do Amazonas), Bahia, Espírito Santo, Goiás, Mato Grosso, Mato Grosso do Sul, Minas Gerais, Paraná, Rio de Janeiro, Rio Grande do Sul, Rondônia, São Paulo, Sergipe, Tocantins e Distrito Federal. A população bovina nessa região foi separada por unidade federativa segundo grupos etários e estratégias de vacinação praticadas no respectivo território. Assim, as 16 unidades federativas envolvidas foram organizadas em 18 subpopulações independentes, de acordo com os esquemas de vacinação empregados. Para cada uma das subpopulações foi realizado um estudo amostral independente. As investigações foram conduzidas pelo Departamento de Saúde Animal (DSA) vinculado à Secretaria de Defesa Agropecuária do Ministério da Agricultura (MAPA) brasileiro e serviços veterinários oficiais nos Estados envolvidos, contando com o apoio do Centro Pan-Americano de Febre Aftosa (PANAFTOSA - OPAS/OMS), principalmente nas fases de planejamento e interpretação dos resultados.

A população alvo foi caracterizada em domínios quanto ao tamanho dos rebanhos e em subpopulações quanto à faixa etária dos bovinos. Com respeito ao tamanho do rebanho foram consideradas três categorias: rebanhos com até 20 bovinos; rebanhos com 21 a 50 bovinos e rebanhos com mais de 50 bovinos. Quanto à faixa etária, foram consideradas as subpopulações constituídas por bovinos entre 6 e 12 meses, bovinos entre 13 e 24 meses e bovinos com mais de 24 meses.

O método analítico empregado para avaliar a resposta imunitária (protegido ou não protegido) de cada indivíduo foi o ELISA-CFL, padronizado pelo PANAFTOSA para detectar anticorpos específicos contra proteínas do capsídeo viral. Todos os ensaios laboratoriais foram realizados no LANAGRO de Pedro Leopoldo, MG, de acordo com manuais e insumos produzidos pelo PANAFTOSA. Cada subpopulação foi testada para um dos três tipos de vírus contido na vacina brasileira $(\mathrm{O}, \mathrm{A}$ e C). As atividades de campo foram conduzidas no período de julho de 2005 a fevereiro de 2006, envolvendo a colheita de 20.423 amostras distribuídas em 1.956 propriedades rurais. Dessas amostras, 1.898 (9\%) foram obtidas em rebanhos com até 20 bovinos; 2.477 (12\%) em rebanhos entre 21 e 50 bovinos; e 16.048 (79\%) em rebanhos com mais de 50 bovinos. Quanto aos grupos etários, foram obtidas 8.565 amostras (42\%) de bovinos entre 6 e 12 meses de idade, 7.017 (34\%), de bovinos entre 13 e 24 meses de idade, e 4.841 (24\%), de bovinos com mais de 24 meses de idade. 
Quanto aos resultados, a análise por subpopulação revelou, para a quase totalidade das unidades federativas, excelentes níveis de cobertura imunitária para a população bovina. As estimativas mais baixas da prevalência de bovinos protegidos para os vírus “O”, "A" e "C", com 95\% de confiança, foram de 87\%; 97\% e 98\% respectivamente, excluindo-se a subpopulação do circuito leste de Minas Gerais onde a estimativa mais baixa foi de $65 \%$ de bovinos protegidos para o vírus “A”. Especificamente em São Paulo, a prevalência aparente de animais protegidos resultou em 84\%, ao passo que a corrigida atingiu 99\% (com nível de confiança de $95 \%$ e erro de amostragem de 15\%). Nesse estudo, foi feita para o Estado de São Paulo apenas a avaliação imunitária contra o vírus tipo A. 


\section{MATERIAL E MÉTODOS}

O estudo realizado foi do tipo transversal, tendo como população alvo bovinos entre seis e 24 meses de idade, vacinados, em algum momento da vida, contra febre aftosa. Deixou-se de fora do estudo animais abaixo de seis meses, pois podem apresentar anticorpos transferidos via colostro da vaca e, além disso, são considerados jovens demais para apresentarem reações imunológicas significativas diante da vacinação, visto que receberam uma ou nenhuma vacina ao longo da vida. Também se optou por não se amostrar animais acima de 24 meses, considerando-se que, em estudos anteriores (MAPA, 2007, p. 34), esses animais manifestaram um perfil imunológico muito semelhante àquele encontrado na faixa etária entre 13 e 24 meses.

A amostragem foi estratificada de acordo com dois parâmetros: idade dos animais e tamanho dos rebanhos. Foram consideradas expectativas diferentes de imunização em animais entre seis e 12 meses e em animais entre treze e 24 meses, assim como entre animais criados em propriedades com até 50 cabeças e em propriedades com mais de 50 cabeças. Dessa forma, os animais foram divididos em quatro grupos, com as respectivas expectativas de proteção expressas na Tabela 1:

\begin{tabular}{clc}
\hline \multirow{2}{*}{ Grupo etário } & \multicolumn{1}{c}{$\begin{array}{c}\text { Extrato } \\
\text { Tamanho do rebanho }\end{array}$} & $\begin{array}{c}\text { Porcentagem esperada de } \\
\text { protegidos }\end{array}$ \\
6 a 12 meses & Até 50 bovinos & $70 \%$ \\
& 50 ou mais bovinos & $75 \%$ \\
13 a 24 meses & Até 50 bovinos & $80 \%$ \\
& 50 ou mais bovinos & $85 \%$ \\
\hline Tabela 1: estratificação das amostras e porcentagem esperada de protegidos por estrato
\end{tabular}

\subsection{Parâmetros para determinação do tamanho da amostra}

O tamanho da amostra foi definido com base nos seguintes parâmetros:

- $\quad$ Nível de confiança: 95,0\%

- $\quad$ Sensibilidade e especificidade do teste: $83,3 \%$ 
- $\quad$ Erro de amostragem: $10,0 \%$

- $\quad$ Erro absoluto: $8,5 \%$

Outro parâmetro que influenciou o tamanho da amostra foi a expectativa de proteção, que variou segundo a faixa etária e o tamanho dos rebanhos. Nesse estudo, utilizou-se $70 \%$ de expectativa de proteção para os bovinos entre 6 e 12 meses de idade nos rebanhos com até 50 animais, e 75\% de proteção para animais da mesma faixa etária em rebanhos maiores. Na faixa etária de 12 a 24 meses em rebanhos com até 50 animais utilizou-se $80 \%$ de expectativa de proteção e em rebanhos maiores, $85 \%$ de proteção na mesma faixa etária.

\subsection{Tamanho e distribuição da amostra}

A amostra foi composta, conforme os parâmetros anteriormente expostos, de 133 bovinos entre seis e 12 meses e de 66 bovinos entre 13 e 24 meses, totalizando 199 animais. Esses animais estavam distribuídos em 18 propriedades com menos de 50 indivíduos e em 33 propriedades com mais de 50 indivíduos, totalizando 51 propriedades. Cada soro colhido foi dividido em três alíquotas iguais (uma para cada tipo de vírus), totalizando 597 amostras.

A escolha das propriedades amostradas foi aleatória, com base no cadastro realizado pela Coordenadoria de Defesa Agropecuária (CDA) do Estado de São Paulo e disponibilizado ao MAPA. A distribuição das propriedades foi estabelecida segundo demonstrado na Tabela 2:

\begin{tabular}{llc}
\hline Regional & Município & Quantidade de propriedades \\
Andradina & Lavínia & 1 \\
Andradina & Mirandópolis & 1 \\
Araçatuba & Araçatuba & 2 \\
Araçatuba & Birigui & 1 \\
Araçatuba & Coroados & 1 \\
Assis & Ibiracema & 1 \\
Avaré & Manduri & 1 \\
Avaré & Taquarituba & 1 \\
Barretos & Bebedouro & 1 \\
Barretos & Cajobi & 1 \\
Bauru & Cabrália Paulista & 1 \\
\hline
\end{tabular}

Tabela 2: distribuição das amostras por município 


\begin{tabular}{|c|c|c|}
\hline Regional & Município & Quantidade de propriedades \\
\hline Bauru & Piratininga & 1 \\
\hline Dracena & Adamantina & 2 \\
\hline Dracena & Mariápolis & 1 \\
\hline Dracena & Pacaembu & 1 \\
\hline Fernandópolis & Fernandópolis & 1 \\
\hline Franca & Patrocínio Paulista & 1 \\
\hline Franca & $\begin{array}{l}\text { Santo Antonio da } \\
\text { Alegria }\end{array}$ & 1 \\
\hline Itapetininga & Capão Bonito & 1 \\
\hline Itapetininga & Guareí & 1 \\
\hline Itapetininga & Sarapuí & 1 \\
\hline Itapetininga & Tatuí & 1 \\
\hline Itapeva & Itapeva & 1 \\
\hline Jales & Jales & 1 \\
\hline Jales & Nova Canaã Paulista & 1 \\
\hline Jaú & Dois Córregos & 1 \\
\hline Jaú & Jaú & 1 \\
\hline Limeira & Corumbataí & 1 \\
\hline Limeira & Rio Claro & 1 \\
\hline Lins & Getulina & 1 \\
\hline Lins & Promissão & 1 \\
\hline Mogi Mirim & Itapira & 1 \\
\hline Mogi Mirim & Mogi Guaçu & 1 \\
\hline Ourinhos & Fartura & 1 \\
\hline Ourinhos & Ipaussu & 1 \\
\hline Ourinhos & Ribeirão do Sul & 1 \\
\hline Presidente Prudente & Presidente Bernardes & 2 \\
\hline Presidente Prudente & Sandovalina & 1 \\
\hline Presidente Venceslau & Santo Anastácio & 1 \\
\hline Ribeirão Preto & São Simão & 1 \\
\hline $\begin{array}{l}\text { São João da Boa } \\
\text { Vista }\end{array}$ & São José do Rio Pardo & 1 \\
\hline São José do Rio Preto & Bady Bassit & 1 \\
\hline São José do Rio Preto & Monte Aprazível & 1 \\
\hline São José do Rio Preto & Palestina & 1 \\
\hline Sorocaba & Pilar do Sul & 2 \\
\hline Tupã & Tupã & 1 \\
\hline Votuporanga & Américo de Campos & 1 \\
\hline \multicolumn{2}{|c|}{ Total } & 51 \\
\hline
\end{tabular}

Tabela 2: distribuição das amostras por município (continuação) 


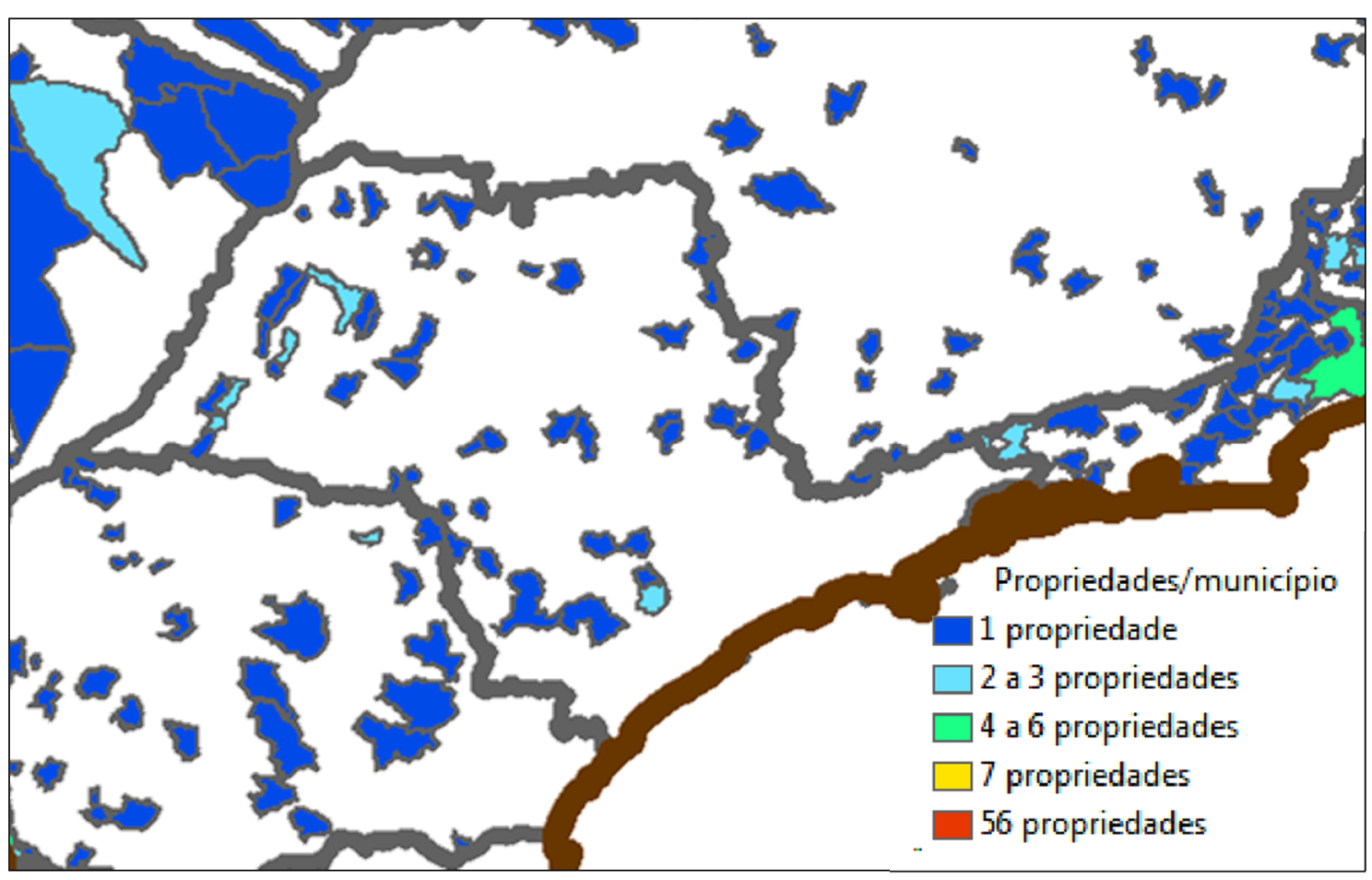

Figura 9: municípios selecionados para o estudo e a concentração de propriedades selecionadas por município.

A escolha dos animais dentro de cada propriedade também se deu de forma aleatória.

A distribuição de animais, em cada propriedade, ocorreu da seguinte maneira:

\begin{tabular}{|c|c|c|c|c|c|c|}
\hline Município & $\operatorname{Reb}^{1}$ & Até $12 \mathrm{~m}^{2}$ & $\begin{array}{l}13 a \\
24 m^{3}\end{array}$ & $\begin{array}{l}\text { Am 6 a } \\
12 m^{4}\end{array}$ & \multicolumn{2}{|c|}{$\operatorname{Am~} 13$ a $24 m^{5}$} \\
\hline Lavínia & $2 \_\geq 50$ & 60 & 8 & & 4 & 2 \\
\hline Mirandópolis & $2 \_\geq 50$ & 6 & 9 & & 3 & 2 \\
\hline Araçatuba & $1 \_<50$ & 13 & 3 & & 3 & 1 \\
\hline Araçatuba & $2 \_\geq 50$ & 0 & 25 & & 3 & 2 \\
\hline Birigui & $2 \_\geq 50$ & 19 & 14 & & 4 & 2 \\
\hline Coroados & $2 \_\geq 50$ & 11 & 13 & & 3 & 2 \\
\hline Ibirarema & $1 \_<50$ & 6 & 4 & & 1 & 1 \\
\hline Manduri & $2 \_\geq 50$ & 17 & 25 & & 3 & 2 \\
\hline Taquarituba & $2 \_\geq 50$ & 10 & 20 & & 3 & 2 \\
\hline Bebedouro & $1 \_<50$ & 2 & 0 & & 1 & 0 \\
\hline Cajobi & $1 \_<50$ & 2 & 4 & & 1 & 1 \\
\hline Cabrália Paulista & $2 \_\geq 50$ & 152 & 0 & & 4 & 1 \\
\hline Piratininga & $2 \_\geq 50$ & 87 & 0 & & 4 & 1 \\
\hline Adamantina & $1 \_<50$ & 6 & 9 & & 1 & 1 \\
\hline Adamantina & $2 \_\geq 50$ & 4 & 6 & & 3 & 1 \\
\hline Mariápolis & $1 \_<50$ & 10 & 0 & & 2 & 0 \\
\hline Pacaembu & $2 \_\geq 50$ & 42 & 2 & & 4 & 1 \\
\hline
\end{tabular}

Tabela 3: distribuição dos animais amostrados por rebanho e município. 


\begin{tabular}{|c|c|c|c|c|c|}
\hline Município & $\operatorname{Reb}^{1}$ & Até $12 \mathrm{~m}^{2}$ & 13 a $24 m^{3}$ & Am 6 a $12 m^{4}$ & Am 13 a $24 m^{5}$ \\
\hline Fernandópolis & $1 \_<50$ & 2 & 1 & 1 & 1 \\
\hline Patrocínio Paulista & $2 \_\geq 50$ & 0 & 45 & 3 & 2 \\
\hline $\begin{array}{l}\text { Santo Antônio da } \\
\text { Alegria }\end{array}$ & $1 \_<50$ & 2 & 0 & 1 & 0 \\
\hline Capão Bonito & $2 \_\geq 50$ & 36 & 5 & 4 & 1 \\
\hline Guareí & $2 \_\geq 50$ & 20 & 0 & 3 & 1 \\
\hline Sarapuí & $2 \_\geq 50$ & 11 & 20 & 3 & 2 \\
\hline Tatuí & $1 \_<50$ & 1 & 7 & 1 & 1 \\
\hline Itapeva & $1 \_<50$ & 0 & 0 & 1 & 0 \\
\hline Jales & $2 \_\geq 50$ & 20 & 0 & 3 & 1 \\
\hline Nova Canaã Paulista & $2 \_\geq 50$ & 24 & 12 & 3 & 2 \\
\hline Dois Córregos & $2 \_\geq 50$ & 0 & 28 & 3 & 2 \\
\hline Jaú & $1 \_<50$ & 0 & 0 & 1 & 0 \\
\hline Corumbataí & $1 \_<50$ & 0 & 17 & 1 & 1 \\
\hline Rio Claro & $1 \_<50$ & 1 & 1 & 1 & 1 \\
\hline Getulina & $2 \_\geq 50$ & 26 & 0 & 4 & 1 \\
\hline Promissão & $2 \_\geq 50$ & 2 & 2 & 3 & 1 \\
\hline Itapira & $2 \_\geq 50$ & 15 & 6 & 3 & 1 \\
\hline Mogi Guaçu & $2 \_\geq 50$ & 96 & 30 & 4 & 2 \\
\hline Fartura & $2 \_\geq 50$ & 0 & 142 & 3 & 2 \\
\hline Ipaussu & $2 \_\geq 50$ & 0 & 0 & 3 & 1 \\
\hline Ribeirão do Sul & $2 \_\geq 50$ & 22 & 0 & 3 & 1 \\
\hline Presidente Bernardes & $1 \_<50$ & 15 & 16 & 2 & 1 \\
\hline Presidente Bernardes & $2 \_\geq 50$ & 41 & 46 & 3 & 2 \\
\hline Sandovalina & $2 \_\geq 50$ & 61 & 58 & 4 & 2 \\
\hline Santo Anastácio & $2 \_\geq 50$ & 37 & 0 & 3 & 1 \\
\hline São Simão & $1 \_<50$ & 1 & 2 & 1 & 1 \\
\hline São José do Rio Pardo & $2 \_\geq 50$ & 34 & 15 & 3 & 2 \\
\hline Bady Bassitt & $2 \_\geq 50$ & 24 & 9 & 4 & 2 \\
\hline Monte Aprazível & $1 \_<50$ & 0 & 1 & 1 & 1 \\
\hline Palestina & $1 \_<50$ & 10 & 3 & 2 & 1 \\
\hline Pilar do Sul & $1 \_<50$ & 4 & 1 & 1 & 1 \\
\hline Pilar do Sul & $2 \_\geq 50$ & 68 & 8 & 4 & 2 \\
\hline Tupã & $2 \_\geq 50$ & 264 & 10 & 3 & 2 \\
\hline Américo de Campos & $2 \_\geq 50$ & 0 & 57 & 3 & 2 \\
\hline Total & & 1284 & 684 & 133 & 66 \\
\hline
\end{tabular}

Tabela 3: distribuição dos animais amostrados por rebanho e município (continuação)

${ }^{1}$ Reb: Tipo de rebanho: pequeno (com menos de 50 animais $=1 \_<50$ ) ou médio (com 50 ou mais animais $=2 \_\geq 50$ )

${ }^{2}$ Até $12 \mathrm{~m}$ : Animais com idade de até 12 meses existentes na propriedade

${ }^{3} 13$ a 24 m: Animais com idade entre 13 e 24 meses existentes na propriedade

${ }^{4} \mathrm{Am} 6$ a12 m: Amostras colhidas de animais com idade entre 6 e 12 meses na propriedade

${ }^{5} \mathrm{Am} 13$ a $24 \mathrm{~m}$ : Amostras colhidas de animais com idade entre 13 e 24 meses na propriedade 


\subsection{Colheita de amostras}

\subsubsection{Obtenção e transporte do soro}

Procedeu-se à colheita de soro dos animais selecionados no fim do período entre campanhas de vacinação contra febre aftosa, entre abril e maio de 2014, de modo que as propriedades visitadas em maio tiveram que adiar a vacinação para depois das colheitas. O período foi escolhido para que houvesse o mínimo de interferência possível da vacinação anterior nos resultados laboratoriais. Em propriedades onde não foram encontrados animais na faixa etária pretendida, procedeu-se à troca de estabelecimentos, respeitando-se similaridades de tamanho e tipo de exploração. Todas as colheitas foram realizadas por médicos veterinários oficiais, do quadro de funcionários da CDA de São Paulo. Os médicos veterinários disponíveis foram distribuídos em vinte e cinco equipes, sob as ordens de um chefe de campo e de um coordenador regional. As equipes foram divididas de acordo com a localização dos Escritórios Regionais da CDA - também chamados de Escritórios de Defesa Agropecuária (EDA) - conforme disposto na Tabela 4.

\begin{tabular}{|c|c|c|c|c|c|}
\hline EDA & Propriedades & Amostras & EDA & Propriedades & Amostras \\
\hline Andradina & 2 & 11 & Limeira & 2 & 4 \\
\hline Araçatuba & 4 & 20 & Lins & 2 & 9 \\
\hline Assis & 1 & 2 & Mogi Mirim & 2 & 10 \\
\hline Avaré & 2 & 10 & Ourinhos & 3 & 13 \\
\hline Barretos & 2 & 3 & Presidente Prudente & 3 & 14 \\
\hline Bauru & 2 & 10 & Presidente Venceslau & 1 & 4 \\
\hline Dracena & 4 & 13 & Ribeirão Preto & 1 & 2 \\
\hline Fernandópolis & 1 & 2 & São João da Boa Vista & 1 & 5 \\
\hline Franca & 2 & 6 & São José do Rio Preto & 3 & 11 \\
\hline Itapetininga & 4 & 16 & Sorocaba & 2 & 8 \\
\hline Itapeva & 1 & 1 & Tupã & 1 & 5 \\
\hline Jales & 2 & 9 & Votuporanga & 1 & 5 \\
\hline Jaú & 2 & 6 & & & \\
\hline
\end{tabular}

Tabela 4: número de unidades regionais (EDAs) envolvidas nos trabalhos de campo.

Para as colheitas, utilizou-se tubos do tipo Vacutainer, com capacidade de $4 \mathrm{~mL}$, e agulha 25 x 0,8 mm. Orientou-se que a colheita fosse realizada com o máximo de higiene possível, com o uso de trajes, botas e macacões limpos e uso de assepsia no local da punção (veia jugular). Foi determinado que o sangue deveria preencher em torno de 2/3 do volume total do tubo. 
Após a colheita, os tubos foram acomodados em estantes específicas, em tempo suficiente até a retração do coágulo. Posteriormente, os tubos com o soro foram centrifugados a uma velocidade de 3.000 a $5.000 \mathrm{rpm}$, durante 5 a 8 minutos. O soro foi então transferido para microtubos previamente identificados com os mesmos códigos dos tubos utilizados na colheita. A transferência foi realizada empregando-se pipeta de Pasteur plástica descartável (à razão de uma pipeta por amostra). Segundo orientação do MAPA, o volume total de soro obtido não poderia ser inferior a $1,0 \mathrm{~mL}$, preenchendo no máximo $2 / 3$ do microtubo.

Cada equipe de colheita contou com um chefe de campo, responsável por verificar a qualidade da colheita. Uma vez checada a limpidez, o volume e a identificação da amostra, o chefe da equipe preenchia a documentação pertinente, descrita mais adiante.

Para encaminhamento das amostras, foram utilizadas uma das seguintes estratégias:

i) Embalagem das amostras em sacos plásticos apropriados, com cada saco contendo as amostras de uma única propriedade;

ii) Organização das amostras em placas de isopor, com distribuição sequencial por propriedade;

iii) Organização das amostras em rack de polipropileno para transporte de microtubos. É de extrema importância que as amostras sejam mantidas congeladas ou sob refrigeração.

As embalagens foram então etiquetadas com as seguintes informações:

- nome do estudo epidemiológico/ano ("Eficiência da vacinação contra febre aftosa"/ 2014);

- código MAPA;

- código da propriedade;

- nome do município e

- número do primeiro e do último frasco das amostras.

As equipes de campo então entregaram as embalagens contendo as amostras sorológicas, acondicionadas em gelo, e os formulários para colheita de amostras correspondentes a um Coordenador Regional, previamente nomeado, que se certificou do 
correto acondicionamento das amostras até o envio à unidade central estadual. Desde o momento da obtenção do soro, as amostras foram mantidas refrigeradas a $4^{\circ} \mathrm{C}$ ou congeladas a $-20^{\circ} \mathrm{C}$.

\subsubsection{Descarte de materiais}

As agulhas para tubo Vacutainer foram descartadas em recipiente com solução desinfetante (Iodophor 1:500, carbonato de sódio a 4\% ou ácido cítrico 0,2\%). Todo material utilizado na sangria foi desinfetado, embalado em saco plástico de lixo e levado da propriedade para o escritório correspondente da CDA. O destino final deste material foi o enterramento ou a incineração.

\subsubsection{Registro das informações}

As informações necessárias ao estudo foram registradas em formulário específico, conforme a figura 6. O preenchimento do formulário também foi feito por médicos veterinários oficiais, com base em verificações in loco e entrevistas com proprietários ou responsáveis pelos animais. As informações básicas referiram-se à identificação da propriedade e do proprietário dos animais, à quantidade de bovinos nos rebanhos susceptíveis existentes, aos últimos registros de vacinação, à identificação da amostra e informações sobre os animais amostrados, como faixa etária, número estimado de vacinações, sexo e origem.

Não houve necessidade de identificação individual dos animais, uma vez que não estava prevista uma segunda colheita. As amostras foram identificadas unindo-se o código da propriedade (padronizado pelo MAPA para todo o território nacional, conforme Manual de Padronização do Departamento de Saúde Animal, versão 18.0 - MAPA, 2014a, p. 20) ao número sequencial da amostra no estabelecimento. 


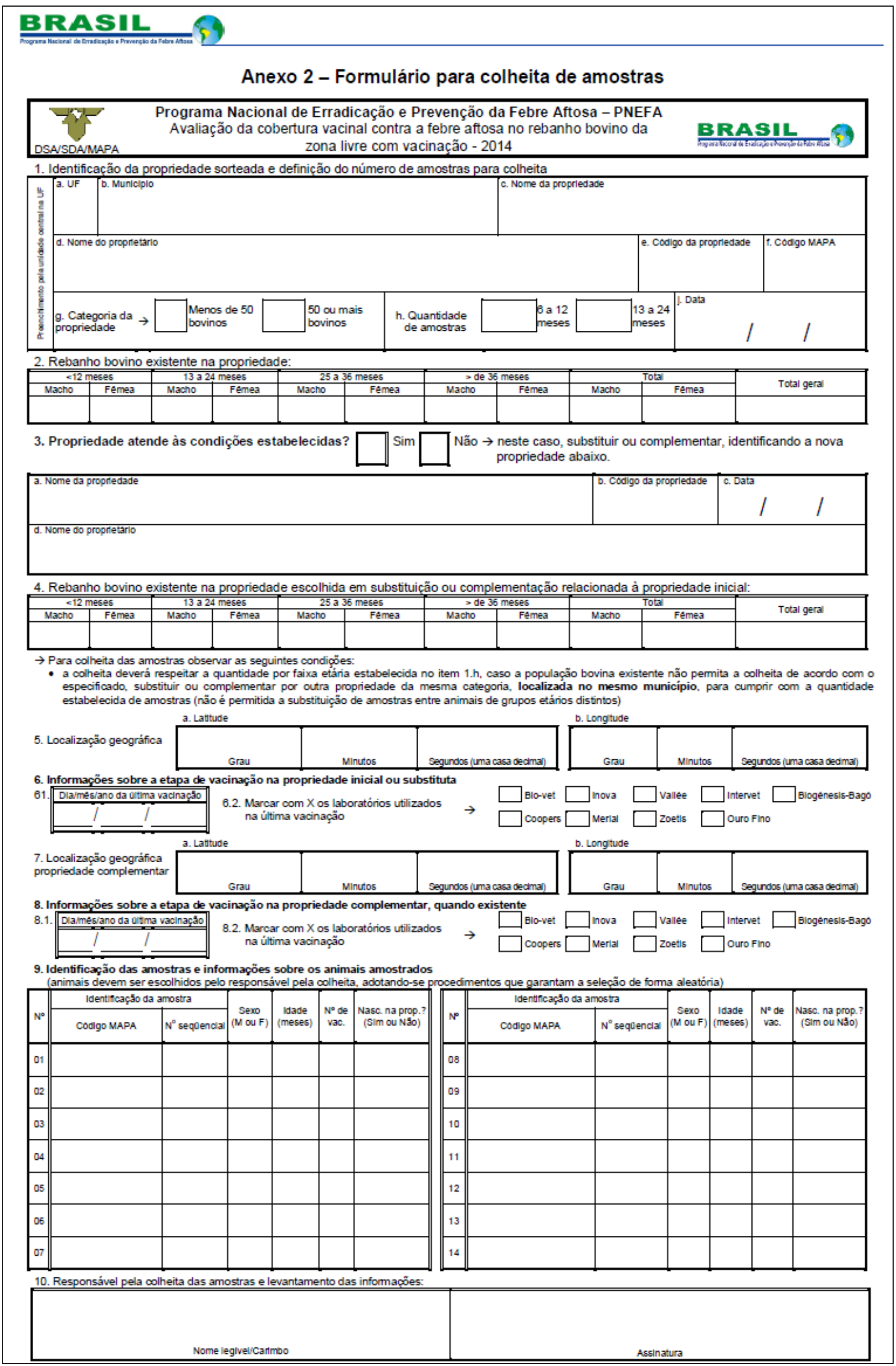

Figura 10: Formulário utilizado para a colheita de amostras (MAPA, 2014a). 


\subsection{Testes laboratoriais}

As amostras obtidas foram encaminhadas para o Centro de Análises e Diagnóstico (CAD) da CDA, para triagem e posterior envio ao Laboratório Nacional Agropecuário de Minas Gerais, em Pedro Leopoldo (LANAGRO/MG), pertencente ao MAPA. Ali, as amostras foram submetidas ao ensaio de ELISA-CFL, desenvolvido pelo Centro Panamericano de Febre Aftosa (PANAFTOSA) para detectar anticorpos específicos contra proteínas do capsídeo viral (proteínas estruturais). O protocolo para a realização do teste de ELISA-CFL, segundo o Manual de Técnicas de Laboratório para o Diagnóstico do em Saúde Animal (IICA, 2001, p. 155), inclui o uso dos materiais listados no Anexo 1.

De acordo com o resultado do teste, os bovinos foram classificados como protegidos ou não protegidos para febre aftosa, considerando como ponto de corte o título de 2,1 para os três tipos de vírus (O1 Campos, A24 Cruzeiro e C3 Indaial) presentes nas vacinas produzidas no país. Para o ponto de corte considerado, o valor da sensibilidade e da especificidade do teste é de $83,3 \%$. Amostras com resultados indeterminados foram submetidas à titulação, de forma a permitir a classificação como protegido ou nãoprotegido.

Os antígenos de referência são as amostras O1 Campos Br-1/58, A24 Cruzeiro Br1/55 e C3 Indaial Br-1/71, obtidos a partir de células BHK (baby hamster kidney), inativados com BEI, tratados com 50\% (v/v) de glicerol estéril e armazenados em alíquotas a $-20^{\circ} \mathrm{C}$. Os anticorpos de captura são obtidos a partir de soros hiperimunes preparados em coelhos, utilizando vírus O1 Campos Br-1/58, A24 Cruzeiro Br-1/55 e C3 Indaial $\mathrm{Br}-1 / 71$, cultivados em células BHK, inativados com BEI, purificados por gradiente de cloreto de césio e armazenados em alíquotas de 0,20 a $3 \mathrm{~mL}$, a $-20^{\circ} \mathrm{C}$. Os anticorpos detectores são obtidos a partir de soros hiperimunes preparados em cobaias com os vírus $\mathrm{O} 1$ Campos Br-1/58,A24 Cruzeiro Br-1/55 e C3 Indaial Br-1/71, adaptados a essa espécie, e armazenados em alíquotas de 0,20 a $3 \mathrm{~mL}$, a $-20^{\circ} \mathrm{C}$. Os soros controles de prova são constituídos por:

- Controle forte positivo $(\mathrm{C}++)$ : pool de soro de bovinos vacinados e revacinados com vacina antiaftosa oleosa monovalente, armazenados a $-20^{\circ} \mathrm{C}$; 
- Controle fraco positivo $(\mathrm{C}+)$ : pool de soros de bovinos de área livre de febre aftosa, misturados com soros de bovinos vacinados, armazenados a $-20^{\circ} \mathrm{C}$;

- Controle negativo: pool de soros de bovinos de área livre de febre aftosa e estomatite vesicular.

Para a realização da prova, a placa deve ser montada conforme o esquema representado na Figura 11:

\begin{tabular}{|c|c|c|c|c|c|c|c|c|c|c|c|c|}
\hline & 1 & 2 & 3 & 4 & 5 & 6 & 7 & 8 & 9 & 10 & 11 & 12 \\
\hline A & $\begin{array}{c}S 1 \\
1: 2\end{array}$ & 1:10 & $1: 50$ & $\begin{array}{l}\text { 1: } \\
250\end{array}$ & $\begin{array}{l}1: \\
1250\end{array}$ & $\begin{array}{l}1: \\
6250\end{array}$ & S5 & & & & & \\
\hline B & $\begin{array}{l}\text { S1 } \\
1: 2\end{array}$ & $1: 10$ & $1: 50$ & $\begin{array}{l}\text { 1: } \\
250\end{array}$ & $\begin{array}{l}\text { 1: } \\
1250\end{array}$ & $\begin{array}{l}\text { 1: } \\
6250\end{array}$ & S5 & & & & & \\
\hline C & S2 & & & & & & S6 & & & & & \\
\hline D & S2 & & & & & & S6 & & & & & \\
\hline E & S3 & & & & & & $\begin{array}{l}\text { C. } \\
1: 2\end{array}$ & $1: 10$ & $1: 50$ & 1:250 & Cag & Cag \\
\hline F & S3 & & & & & & $\begin{array}{l}\mathrm{C}_{+} \\
1: 10\end{array}$ & $\begin{array}{l}1: \\
1: 50\end{array}$ & $1: 250$ & $1: 1250$ & Cag & Cag \\
\hline G & S4 & & & & & & $\begin{array}{l}\mathrm{C}_{++} \\
1: 200\end{array}$ & $1: 100$ & 1:5000 & $1: 2500$ & Cag & Cag \\
\hline H & S4 & & & & & & Blanc & Blanc & Blanc & Blanc & Blanc & Blanc \\
\hline
\end{tabular}

Figura 11: Esquematização do teste de ELISA-CFL na placa de microtitulação, com respectivas diluições. S: Soro

C-: Controle negativo

$\mathrm{C}+$ : Controle positivo fraco

$\mathrm{C}++$ : Controle positivo forte

Cag: Controle do antígeno

Blanc: Controle branco

Para preparo da fase sólida, os seguintes passos foram seguidos:

- Lavagem da placa, com a finalidade de utilizar uma vez com água destilada

- Escorrimento sobre papel absorvente

- Adição, em cada cavidade da placa, de $100 \mu \mathrm{L}$ de anticorpos de captura na diluição de uso, em tampão Carbonato;

- Incubação por 18 horas a $4^{\circ} \mathrm{C}$ 
- Retirada da placa do refrigerador 30 minutos antes do início da prova;

- Lavagem com solução salina fisiológica;

- Adição, em cada poço da placa, de $100 \mu \mathrm{L}$ de ovoalbumina GV a $1 \%$ em PBS;

- Incubação por 1 hora a temperatura ambiente $\left(22^{\circ}-25^{\circ} \mathrm{C}\right)$;

- Lavagem com solução salina fisiológica;

- Escorrimento sobre papel absorvente.

Para a obtenção da fase líquida, devem ser seguidas as seguintes etapas:

- Adição de $40 \mu \mathrm{L}$ de solução de tampão de diluição em colunas 2 a 6 e 8 a 12 . Na linha H, colunas 7 a 12 (controle branco) adicionar o dobro de volume de tampão de diluição;

- Adição de $50 \mu \mathrm{L}$ dos soros problemas em seus respectivos poços;

- Adição, em E7, de $50 \mu \mathrm{L}$ de soro controle negativo; em F7, $50 \mu \mathrm{L}$ de diluição 1:5 de soro controle positivo fraco; em $\mathrm{G} 7,50 \mu \mathrm{L}$ da diluição 1:100 do soro controle positivo forte;

- Preparação, com pipeta multicanal, das diluições base 5 dos soros, passando 10 $\mu \mathrm{L}$ da coluna 1 para a coluna 2 . Homogeneização e passagem de $10 \mu \mathrm{L}$ da coluna 2 para a coluna 3. Continuação até a coluna 6 e descarte dos últimos $10 \mu \mathrm{L}$;

- Preparação, com ponteiras limpas, das diluições na segunda metade das placas nas linhas $\mathrm{A}$ a $\mathrm{D}$, passando $10 \mu \mathrm{L}$ da última coluna 7 a coluna 8 , homogeneização e passagem de $10 \mu \mathrm{L}$ da coluna 8 para a 9. Continuação até a coluna 12 e descarte dos últimos $10 \mu \mathrm{L}$;

- Diluição dos soros controle nas linhas E, F e G, colunas 7 a 10. Passagem de 10 $\mu \mathrm{L}$ da coluna 7 a coluna 8 , homogeneização e passagem de $10 \mu \mathrm{L}$ da coluna 8 para a coluna 9. Homogeneização e passagem de $10 \mu \mathrm{L}$ da coluna 9 para a coluna 10. Homogeneização e descarte dos $10 \mu \mathrm{L}$ excedentes da coluna 10 ;

- Reserva das linhas E, F e G, colunas 11 e 12 para o controle do antígeno;

- Adição da diluição correspondente do antígeno, em volume de $40 \mu \mathrm{L}$ em todos os poços, exceto os correspondentes ao controle branco (H7 a 12); 
- Homogeneização com batidas suaves das bordas da placa;

- Incubação durante uma hora a $37^{\circ} \mathrm{C}$ com agitação;

- Transferência de $50 \mu \mathrm{L}$ da mistura do soro/antígeno da placa auxiliar para a placa sensibilizada com soros de captura (fase sólida);

- Incubação por 30 minutos a $37^{\circ} \mathrm{C}$ com agitação;

- Lavagem, por três vezes, com solução de lavado;

- Adição de $50 \mu \mathrm{L}$ de anticorpo detector;

- Incubação por 30 minutos a $37^{\circ} \mathrm{C}$ com agitação;

- Lavagem, por três vezes, com solução de lavado;

- Adição de $50 \mu \mathrm{L}$ de conjugado em toda a placa;

- Incubação por 30 minutos a $37^{\circ} \mathrm{C}$ com agitação;

- Lavagem, por quatro vezes; com solução de lavado;

- Adição de $50 \mu \mathrm{L}$ do substrato em toda a placa;

- Incubação, sob proteção da luz, por 15 minutos em temperatura ambiente $\left(25^{\circ} \mathrm{C}\right)$;

- Inibição da reação pela adição de $50 \mu \mathrm{L}$ de ácido sulfúrico $3 \mathrm{~N}$ em cada um dos poços.

- Leitura em leitor de ELISA com filtro $492 \mathrm{~nm}$

- Interpretação dos resultados:

As leituras de densidade óptica (DO) da placa são processadas pelo software de titulação de anticorpos de PANAFTOSA para a interpretação da placa. Os valores de DO do controle de antígeno são considerados como em $100 \%$ da cor da placa e os valores de DO do branco são subtraídos do DO de cada cavidade.

O cálculo dos títulos de $50 \%$ de cada um dos soros se realiza de forma individual para cada soro da seguinte maneira:

- Interpolação linear- Provas de titulação: 
1) Calcular a medida de densidade óptica (DO) de controle do antígeno (X). Obter $50 \%$ desse valor médio $(\mathrm{Y})$;

2) Escolher a leitura de DO do soro a titular que seja superior (A) e a inferior (B) ao valor médio obtido anteriormente (Y) e subtrair um do outro (Z)

3) Subtrair do valor (Y) a leitura inferior (B)

4) Multiplicar o valor obtido em (3), pelo logaritmo do intervalo de diluição do soro (fator de diluição $5=0.7)(C)$

5) Dividir o valor obtido em (4), $\{(\mathrm{Y}-\mathrm{B}) \mathrm{C}\}$ pelo valor de $\mathrm{Z}$

6) Somar o valor obtido em (5) com o logaritmo de diluição da leitura inferior (D)

Ao final, o cálculo do título pode ser representado da seguinte maneira:

$\mathrm{Y}=\mathrm{X} / 2$

$\mathrm{Z}=\mathrm{A}-\mathrm{B}$

TIT. $50 \%=[\{(\mathrm{Y}-\mathrm{B}) \mathrm{C}\} / \mathrm{Z}]+\mathrm{D}$

\subsection{Tratamento dos dados}

Com base nos resultados laboratoriais disponibilizados pelo LANAGRO/MG, para cada subpopulação considerada, foram calculadas as prevalências pontuais aparentes para os três tipos de vírus, ajustadas de acordo com a participação (peso) do total de animais por estrato.

Para determinação da prevalência pontual corrigida (ou verdadeira) e cálculo dos limites de confiança, foi utilizado o método proposto por LEW; LEVY, 1989, p. 12251230, estimador "Bayesiano", empregando-se o programa X(PLORE), ajustada com base na participação do rebanho bovino por estrato considerado. 


\section{RESULTADOS E DISCUSSÃO}

Considerando os dados brutos (não tratados) do estudo, foram colhidos soros de 199 animais, divididos em três alíquotas iguais (uma para cada tipo de vírus), totalizando 597 amostras. Dessas, 412 (69,01\%) foram consideradas reagentes ("protegidos") e 185 $(30,99 \%)$ não reagentes ("não protegidos"). Considerando a estratificação por tamanho de rebanho, verificou-se que, nas pequenas propriedades (rebanho menor que 50 cabeças), obteve-se $84(77,77 \%)$ amostras reagentes e 24 (22,22\%) não reagentes, em um total de 108 amostras. Nas grandes propriedades (rebanho acima de 50 cabeças), obteve-se 328 $(67,07 \%)$ reagentes e 161 (32,92\%) não reagentes, em um total de 489 amostras (Gráfico 2).

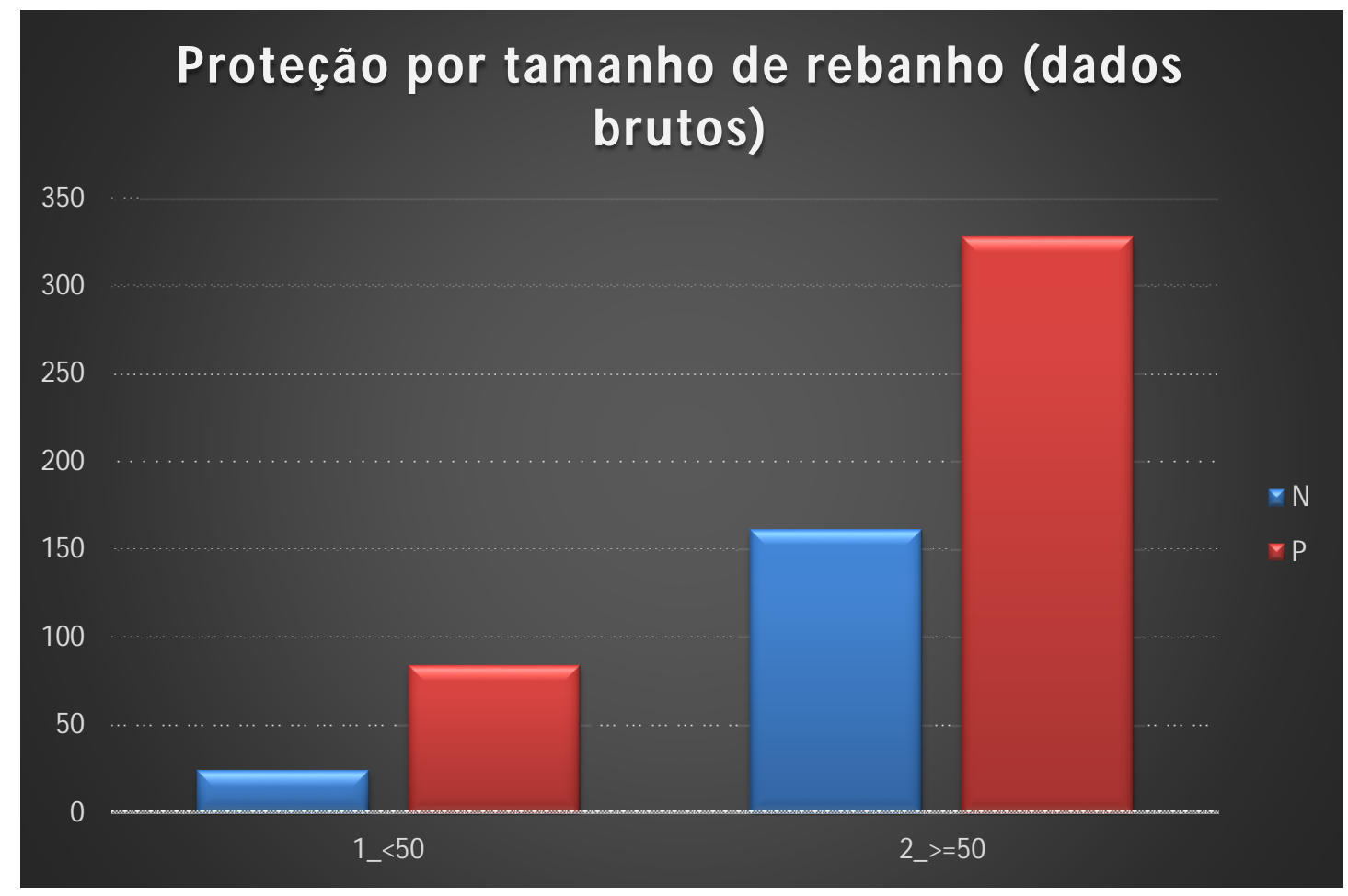

Gráfico 2: Quantidade de amostras de animais protegidos e não protegidos, segundo tamanho rebanho. $\mathrm{N}$ : Não protegidos

P: Protegidos

Esses dados sugerem um melhor perfil imunitário nas pequenas propriedades, quando comparadas às grandes, o que contraria estudos anteriores (MAPA, 2007, p. 34) e o conhecimento prático do SVO quanto às tendências de notificação de vacinação durante as campanhas oficiais. Uma das possíveis explicações para o atual achado seria que os grandes pecuaristas, mais preocupados com acesso a mercados, teriam durante anos mantido alto rigor quanto à vacinação contra febre aftosa, mas, ao não constatarem a presença da doença a campo nos últimos vinte e dois anos (o último foco no Estado foi 
em 1996), teriam se descuidado com relação às ações de prevenção, não acreditando mais na possibilidade de reintrodução da doença.

Considerando a estratificação por idade, foram colhidas amostras de soro de 133 animais entre seis e 12 meses de idade e de 66 animais entre 13 e 24 meses. Entre os animais mais jovens, $87(65,41 \%)$ apresentaram reatividade para pelo menos um dos vírus estudados, ao passo que entre os mais velhos, esse número foi de 49 (74,24\%). Tal achado sugere uma melhor proteção entre animais mais erados, o que coincide com o conhecimento prévio que se possui sobre a doença e sobre o perfil de resposta imunitária à vacina (MAPA, 2007, p. 34). Animais entre seis e 12 meses devem, pelo calendário oficial de vacinação, ter recebido entre uma e duas doses da vacina; ao passo que animais entre 13 e 24, com maior número de doses administradas, apresentam maior capacidade de resposta maior em decorrência do efeito "booster", no qual novas doses elevarão a amplitude e a duração da curva de anticorpos produzidos pelo sistema imune (Gráfico 3).

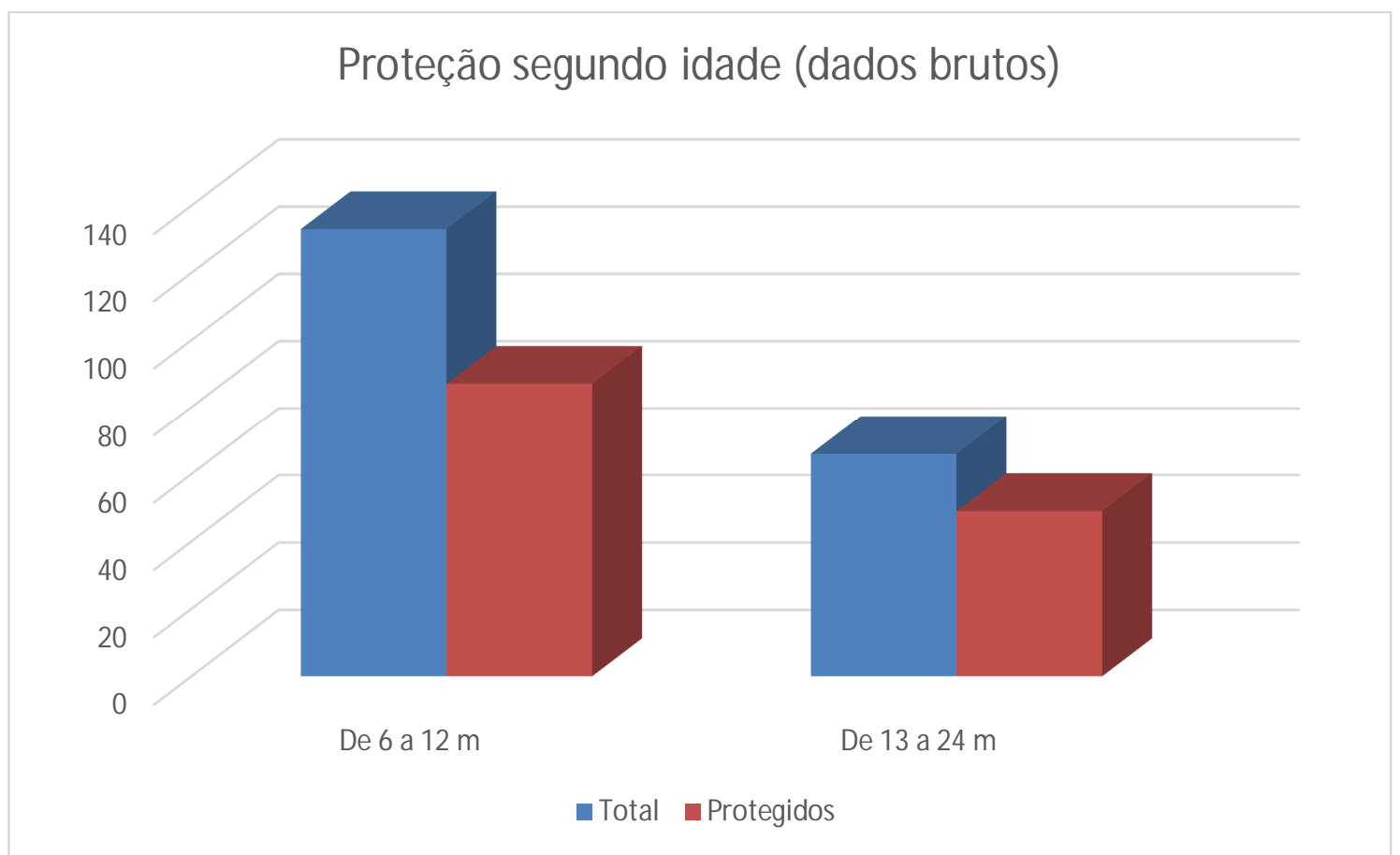

Gráfico 3: Quantidade de amostras de animais protegidos e totais, segundo tamanho idade.

Uma vez tratados os dados, obteve-se a prevalência aparente (ajustada com base na participação de cada extrato de bovinos na população total) e a prevalência corrigida de animais protegidos, por tipo de vírus. Os resultados das prevalências pontuais aparentes e corrigidas, considerando o intervalo de confiança de $95 \%$ para a última, são apresentados na Tabela 5, estratificada por tipo de vírus. 


\begin{tabular}{|c|c|c|c|c|}
\hline \multicolumn{5}{|c|}{ Amostras: 199} \\
\hline \multicolumn{5}{|c|}{ Vírus 0} \\
\hline Protegidos & Prev. Aparente* & Prev. Corrigida & \multicolumn{2}{|c|}{ IC 95\% } \\
\hline 123 & $69,6 \%$ & $78,2 \%$ & $77,1 \%$ & $79,2 \%$ \\
\hline \multicolumn{5}{|c|}{ Vírus A } \\
\hline Protegidos & Prev. Aparente* & Prev. Corrigida & \multicolumn{2}{|c|}{ IC 95\% } \\
\hline 136 & $701 \%$ & $799 \%$ & $790 \%$ & $809 \%$ \\
\hline \multicolumn{5}{|c|}{ Vírus C } \\
\hline Proteaidos & Prev Anarente* & Prev Corriaida & \multicolumn{2}{|c|}{ IC 95\% } \\
\hline & & & LI & LS \\
\hline 140 & $72,8 \%$ & $82,6 \%$ & $81,7 \%$ & $83,4 \%$ \\
\hline
\end{tabular}

Tabela 5: Prevalências aparente e corrigida e intervalo de confiança para prevalência corrigida referentes ao total de bovinos protegidos, segundo tipo de vírus.

* ajustada com base na participação (peso) do total de bovinos por extrato

IC 95\% = Intervalo com 95\% de confiança, LI = limite inferior, $\mathrm{LS}=$ limite superior

A prevalência corrigida de animais protegidos variou de 78,2\% a 82,6\% para os tipos de vírus considerados. A pequena variação para proteção contra três vírus encontrada em animais vacinados com vacinas trivalentes pode ser creditada a diferenças individuais na resposta imune. Considerando a determinação do MAPA para uma cobertura vacinal mínima de 80,0\% (MAPA, 2014b, p.7), o Estado de São Paulo apenas atingiria a proteção adequada para o vírus $\mathrm{C}$, embora, levando-se em conta a margem de erro, o limite superior da proteção projetada contra o vírus A também atinja esse objetivo. Vale lembrar que o vírus $\mathrm{C}$ foi recentemente retirado da formulação da vacina, por ter sido considerado erradicado do continente, de modo que as próximas campanhas de vacinação serão realizadas apenas contra os vírus O e A (BRASIL, 2018, p. 4).

Assim, o Estado de São Paulo, na classificação adotada pelo MAPA (MAPA, 2015, p.8), foi alocado no grupo 3, de acordo com os seguintes critérios:

- Grupo 1: subpopulações com valor igual ou maior a 90\% para, pelo menos, dois tipos de vírus e nenhum valor inferior a $80 \%$ (excelente nível de imunidade de rebanho);

- Grupo 2: subpopulações com valor entre $80 \%$ e $89 \%$ para, pelo menos, dois tipos de vírus (satisfatório nível de imunidade de rebanho);

- Grupo 3: subpopulações com valor inferior a $80 \%$ para pelo menos dois tipos de vírus (inadequado nível de imunidade de rebanho). 
Dessa forma, o Estado de São Paulo foi instado a elaborar plano de ação para incrementar a divulgação e fiscalização das etapas de vacinação contra febre aftosa. Foi considerado que o não atendimento dos níveis mínimos de proteção esperados pode dever-se a vários fatores, tais quais:

- Quebra da cadeia de frio, em qualquer etapa entre a produção e a aplicação da vacina no animal;

- Susceptibilidade individual dos animais, que inclui também quadros como subnutrição, ocorrência de enfermidades, e outros fatores de imunodepressão;

- Má aplicação da vacina, em local, quantidade ou via de administração inadequada;

- Higiene inadequada no momento da aplicação da vacina, com subsequente formação de abscessos;

- Não aplicação da vacina.

Não foi levada em conta uma possível falta de qualidade da vacina, uma vez que todas as partidas são submetidas a testes oficiais realizadas em laboratório do MAPA, sendo apenas liberadas para o comércio aquelas que atenderem os padrões mínimos estabelecidos pela legislação vigente (BRASIL, 2018, p. 4). De acordo com as normas em vigor, $100 \%$ das partidas de vacinas contra febre aftosa produzidas ou importadas pelo país são submetidas aos seguintes controles:

- Controle de esterilidade, para descartar possíveis contaminações de fungos, bactérias e demais agentes biológicos;

- Controle de vírus residual ativo, com passagens em meio de cultura ou testes em bovinos vivos, para garantia de ausência de atividade viral;

- Controle de potência, por meio da prova de ELISA-CFL ou prova de Proteção à Generalização Podal- PGP;

- Controle de proteínas não estruturais, por meio do sistema ELISA 3ABC/EITB.

Dessa forma, garantindo-se a potência das vacinas, conforme descrito acima, são descartados problemas inerentes à fabricação do produto. Considerando os demais fatores 
levantados, previamente descritos, o plano de ação do Estado de São Paulo foi redigido elencando as seguintes prioridades:

1. Agendamento de reuniões com a Coordenadoria de Assistência Técnica Integral (CATI) e a Federação de Agricultura do Estado de São Paulo (FAESP), visando ao apoio dessas entidades no sentido de disponibilizar servidores para acompanharem a vacinação contra a febre aftosa nos meses de campanha de vacinação;

2. Agendamento de reuniões com prefeituras municipais nas regiões de pior desempenho no estudo, visando ao apoio dessas entidades no sentido de disponibilizar servidores para acompanharem a vacinação contra a febre aftosa nos meses de campanha de vacinação;

3. Agendamento de reunião com o Comitê Estadual de Educação Sanitária para traçar estratégias visando ao incremento de sensibilização dos produtores rurais quanto à importância da vacinação contra febre aftosa;

4. Realização de treinamento com técnicos agropecuários e médicos veterinários do quadro da CDA, com enfoque em boas práticas de manejo voltadas á vacinação contra febre aftosa;

5. Ampliação das auditorias internas nas unidades regionais da CDA, com colaboração da SFA/SP;

6. Cumprimento integral da meta determinada pelo Plano Plurianual (PPA) no tocante à vacinação assistida e à fiscalização de revendas. Atualmente, a meta determinada pela sede da CDA é de realização de vacinação assistida em $2 \%$ das propriedades sob jurisdição de cada regional, bem como a realização de dezoito fiscalizações por revenda de vacinas por ano.

Também é válido ressaltar que, em comparação ao estudo anterior, realizado pelo MAPA em 2007 (p. 33), os índices caíram drasticamente: a média de prevalência de proteção para os três vírus era então de $99 \%$, tendo caído desde então para 80,23\%. A não ocorrência de febre aftosa em mais de vinte anos no Estado (o último foco notificado ocorreu em 1996) pode explicar um menor cuidado do pecuarista em manter seus animais protegidos. 
Outros países que utilizam a vacinação massal como ferramenta de controle ou erradicação da febre aftosa têm conduzido estudos de eficiência da vacina, embora esses estudos nem sempre sejam publicados. Como a América do Sul é uma região que se caracteriza pelo uso da vacinação massal - ao contrário da América do Norte e Europa é nesse continente que foram conduzidos quase todos os estudos similares sobre resposte imune do rebanho imunizado. O Peru, por exemplo, conduziu dois inquéritos soroepidemiológicos sobre o tema, um em 2010 e outro em 2011 (SENASA, 2012, p. 1). Nesses estudos, dividiu-se o rebanho em três categorias, segunda a faixa etária dos animais, agrupando-os em bezerros, novilhos/novilhas e vacas/touros. Em 2010, os animais mais jovens apresentaram 46\% de imunização, ao passo que os novilhos obtiveram $68 \%$, e os animais adultos, $85 \%$. A média foi de 70,5\%. No ano seguinte, os valores saltaram, respectivamente, para $65,4 \%, 69,4 \%$ e $86,0 \%$, com média de 75,6\%. O avanço mais marcante foi na imunização dos bezerros, que saltou quase vinte pontos percentuais em um ano. É difícil comparar esses dados com aqueles obtidos pelo Estado de São Paulo, pois a média do estudo brasileiro foi feita considerando o peso por extrato etário dos animais envolvidos, ao passo que, no Peru, utilizou-se a média aritmética simples. Ainda assim, pode se observar um bom índice de imunização nos animais adultos, acima de $85 \%$. De fato, a autoridade sanitária peruana considerou os resultados adequados: o Programa Nacional de Erradicação de Febre Aftosa daquele país determina que bezerros tenham índice de proteção mínimo de 65\%, novilhos de $75 \%$ e adultos de $85 \%$. As metas foram atingidas parcialmente no estudo de 2010 e integralmente no de 2011.

Um ano após o último estudo peruano, o Uruguai também conduziu um inquérito epidemiológico de resposta imune à vacina contra febre aftosa (MGAP, 2012, p. 34). O estudo foi realizado nas semanas imediatamente anteriores ao início da campanha de vacinação - período mais crítico, do ponto de vista imunológico, para os resultados de níveis de anticorpos séricos nos animais alvo do inquérito. A exemplo do estudo conduzido no Peru, os animais foram agrupados, de acordo com sua faixa etária, em três grupos: de animais de 6 a 12 meses, de 13 a 24 meses, e acima de 24 meses. Os resultados obtidos para cada faixa etária foram, respectivamente, de 68\%,77\% e 97\%, com média geral de $87,9 \%$. O resultado foi considerado como excelente pelas autoridades sanitárias uruguaias. Mais uma vez, como ocorreu no caso peruano, é difícil comparar a situação do Uruguai com a do estado de São Paulo, devido à metodologia divergente no cálculo das 
médias. Ainda assim, chama a atenção os bons resultados uruguaios, em especial dos animais adultos - que beiraram os $100 \%$ de proteção.

A tentativa de se estabelecer estimativas de taxas de proteção contra a febre aftosa no rebanho não é nova. Já na década de 1990, as autoridades sanitárias argentinas conduziam estudos de imunidade populacional em seu rebanho. Em 1995, um inquérito epidemiológico conduzido pelo SVO daquele país, segundo FONDEVILA et al., 1997, p. 784, concluiu que $77 \%$ dos animais até 12 meses de idade apresentavam níveis de proteção adequada contra a febre aftosa. Para animais adultos, a proporção subia para 94\%. Mais uma vez, mesmo em face de metodologias diferentes em relação ao presente estudo, é se destacar o bom desempenho do rebanho argentino.

Os resultados obtidos em outros países da América do Sul, bem como estudos anteriores no próprio Estado, reforçam a ideia de que a preocupação em vacinar de maneira adequada o rebanho vem caindo ano a ano entre os produtores de São Paulo.

Vale ressaltar que, mesmo uma vez erradicada a doença no país, existe o risco de reintrodução da doença, e que uma das ferramentas de prevenção é a vacinação. A reintrodução do vírus pode se dar por diversos modos, com destaque para o trânsito irregular de animais e produtos. A experiência brasileira mostra que já foram isolados agentes patógenos em produtos trazidos ilegalmente para o Brasil. MELO et al., 2015, p. 25, demonstraram a presença de Listeria monocytogenes em 22,9\% e de Staphylococcus auerus em 14,58\% de produtos apreendidos pela Vigilância Agropecuária Internacional nos Aeroportos de Guarulhos/São Paulo e do Galeão/Rio de Janeiro. Não se trata de patógenos de doenças de controle oficial no âmbito de saúde animal, mas a constatação ilustra a possibilidade de ingresso de agentes etiológicos por meio do trânsito de produtos de origem animal.

Em um estudo ainda mais preocupante, MELO et al., 2014, p. 1934, demonstraram a presença de Mycbacterium bovis em 17,5\% e de Brucella sp em 42,1\% de produtos leiteiros apreendidos pela Vigilância Agropecuária Internacional, nos mesmos aeroportos. À diferença do outro estudo publicado pelos mesmos autores, tratava-se de agentes de doenças de controle oficial. As origens desses produtos foram tão variadas quanto Itália, Portugal, Espanha, França, Argentina, Holanda, Estados Unidos, Líbano, Marrocos, Iraque, Peru, Israel e Turquia. 
Vale lembrar que o Estado de São Paulo, embora não possua fronteiras internacionais, conta com o aeroporto internacional com o maior fluxo de passageiros estrangeiros (Guarulhos), o maior aeroporto de cargas (Viracopos) e o maior Porto (Santos) do Brasil (CGNA, 2017, p. 11; ANTAQ, 2017, p. 1). A reintrodução do vírus por meio do trânsito, em especial de produtos ilegais, não é um cenário desprezível na atual realidade do Estado.

O PNEFA nos próximos anos, portanto, deve se focar na prevenção da reintrodução da febre aftosa em áreas livres. Nesse contexto, a fim de melhorar os índices vacinais contra a febre aftosa no Estado de São Paulo, a CDA, em parceria com o MAPA, deve reforçar suas ações junto aos produtores para:

1. Conscientização quanto à importância do uso da vacina, e fiscalizar a vacinação no maior número possível de estabelecimentos;

2. Conscientização quanto à importância da manutenção da cadeia do frio, fiscalizando os pontos que lhe cabem (da fabricação às revendas);

3. Capacitação de produtores, veterinários e trabalhadores rurais quanto ao correto uso da vacina, tanto no que se refere ao local de aplicação (tábua do pescoço), quanto à quantidade (5 mL até 2019, $2 \mathrm{~mL}$ a partir de então), quanto às vias de aplicação (intramuscular e subcutânea).

Dessa forma, pretende-se manter elevado o nível de proteção do rebanho contra a febre aftosa, ao menos até quando a estratégia de prevenção mudar, com a retirada da vacinação - o que está previsto para acontecer em São Paulo no ano de 2021. 


\section{CONCLUSÕES}

- Avaliou-se o resultado das ações do Programa de Erradicação da Febre Aftosa no Estado de São Paulo, com foco no perfil imunitário do rebanho bovino vacinado contra o vírus da febre aftosa, no ano de 2014;

- O rebanho bovino paulista apresentou níveis de proteção para febre aftosa de 78,2\% para o vírus $\mathrm{O}, 79,9 \%$ para o vírus A e $82,6 \%$ para o vírus $\mathrm{C}$, pelo método de ELISACFL;

- Para dois sorotipos estudados (A e O), os índices de proteção apresentaram níveis abaixo daqueles preconizados pelo MAPA $(80,0 \%)$;

- Esses dados forneceram subsídios para ações de fortalecimento da estrutura dos programas sanitários e dos sistemas de atenção veterinária do Estado de São Paulo, com enfoque no fomento da cooperação técnico-científica entre Instituições de Pesquisa, Instituições de Extensão, MAPA e Coordenadoria de Defesa Agropecuária do Estado de São Paulo. 


\section{REFERÊNCIAS BIBLIOGRÁFICAS (SILVA; SANTOS, 2017)}

ALAM, S. et al. Antigenic heterogeneity of capsid protein VP1 in foot-and-mouth disease virus (FMDV) serotype Asia 1. Advances and Applications in Bioinformatics and Chemistry, Auckland, v. 6, p. 37-46, 2013. Disponível em: < https://www.ncbi.nlm.nih.gov/pmc/articles/PMC3751384/>. Acesso em: 06 jan. 2018.

ALLENDE, R. M. ELISA competición fase liquida (ELISA-CFL) y su uso en control de potencia de vacunas antiaftosa. In: SEMINARIO INTERNACIONAL DE CONTROL DE VACUNA ANTIAFTOSA, 7., 2001, Rio de Janeiro. Rio de Janeiro: Centro Panamericano de Fiebre Aftosa - Organización Panamericana de la Salud/ Organización Mundial de la Salud, 2001. p. 13-20. Disponível em: https://www.paho.org/panaftosa/index.php?option=com_docman\&view=download\&cat egory slug=informes-802\&alias=37-informe-final-vii-seminario-internacional-controlvacuna-antiaftosa-7\&Itemid=518>. Acesso em: 06 dez. 2016.

ANTAQ. Agência Nacional de Transportes Aquaviárioa. Anuário Estatístico Aquaviário. 2017. Disponível em: < http://web.antaq.gov.br/Anuario/>. Acesso em: 09 set. 2018.

APHIS. Animal and Plant Health Inspection Service. FMD in Greece. 2000. Disponível em:

https://www.aphis.usda.gov/animal_health/emergingissues/impactworksheets/iw_2000_ files/foreign/fmd_greece0700e.htm>. Acesso em: 25 mar. 2017.

ARANDA, C. M. S. S.; MORAES, J.C. Rede de frio para conservação de vacinas em unidades públicas do município de São Paulo: conhecimento e prática. Revista brasileira de epidemiologia, São Paulo, v. 9, p. 172-185, 2006. Disponível em: < http://www.scielo.br/pdf/rbepid/v9n2/04.pdf/>. Acesso em: 09 set. 2018.

BACHRACH, H. L. Foot and mouth disease virus. Annual Review of Microbiology, Palo Alto, v. 22, p. 201-204, 1968.

BOTTON, S. A. Atividade do interferon tipo I suíno na proteção contra o vírus da febre aftosa. 2005. 95 f. Tese (Doutorado em Medicina Veterinária) - Universidade Federal de Santa Maria, Santa Maria, 2005. Disponível em: 
<http://repositorio.ufsm.br/bitstream/handle/1/4069/SONIABOTTON.pdf?sequence=1

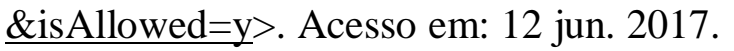

BRASIL. Ministério da Agricultura, Pecuária e Abastecimento. Instrução Normativa $\mathrm{n}^{\circ}$ 44, de 02 de outubro de 2007. Aprova as diretrizes gerais para a Erradicação e a Prevenção da Febre Aftosa. Diário Oficial da República Federativa do Brasil, Poder Executivo, Brasília, 3 out. 2007. Seção 1, p. 2-10.

BRASIL. Ministério da Agricultura, Pecuária e Abastecimento. Instrução Normativa $\mathrm{n}^{\circ}$ 50, de 23 de setembro de 2008. Aprova o Regulamento Técnico para a Produção, Controle de Qualidade, Comercialização e Emprego de Vacinas contra a Febre Aftosa. Diário Oficial da República Federativa do Brasil, Poder Executivo, Brasília, 24 set. 2008. Seção 1, p. 1.

BRASIL. Ministério da Agricultura, Pecuária e Abastecimento. Instrução Normativa MAPA n 36, de 08 de setembro de 2017. Reconhece os Estados do Amapá, Amazonas e zona de proteção do Pará como zona livre de Febre Aftosa com vacinação. Diário Oficial da República Federativa do Brasil, Poder Executivo, Brasília, 8 dez. 2017. Seção 1, p. 20 .

BRASIL. Ministério da Agricultura, Pecuária e Abastecimento. Instrução Normativa MAPA n 11, de 18 de janeiro de 2018. Aprova o Regulamento Técnico para a Produção, Controle de Qualidade, Comercialização e Emprego de Vacinas contra a Febre Aftosa. Diário Oficial da República Federativa do Brasil, Poder Executivo, Brasília, 22 jan. 2018. Seção 1, p. 4-5.

CENTRO PANAMERICANO DE FIEBRE AFTOSA (PANAFTOSA). Série de manuais didáticos. $1978 . \quad$ Disponivel em:< http://bvs1.panaftosa.org.br/local/File/textoc/Sit1999esp.pdf >. Acesso em: 11 dez. 2016. CGNA. Centro de Gerenciamento da Navegação Aérea. Anuário Estatístico de Tráfego Aéreo. 2017. Disponível em: <http://portal.cgna.gov.br/files/uploads/anuario estatistico/anuario estatistico 2017.pdf z. Acesso em: 09 set. 2018.

CUNLIFFE, H. R.; GRAVES, J. H. Formalin-treated foot-and-mouth disease virus: comparison of two adjuvants in cattle. Canadian Journal of Comparative Medicine 
and Veterinary Science, Ottawa, v. 27, n. 8, p. 193-197, 1963. Disponível em: <https://www.ncbi.nlm.nih.gov/pmc/articles/PMC1583692/>. Acesso em: 11 dez. 2017.

DOEL, T. R. Optimization of the immune response to foot-and-mouth disease vaccines. Vaccine, Auckland, v. 17, p. 1767-1771, 1999. Disponível em: < https://ac.elscdn.com/S0264410X98004447/1-s2.0-S0264410X98004447-main.pdf? tid=c8484605$\underline{1707-4987-8 \mathrm{~cd} 2-}$ 46f99198ee93\&acdnat=1528304347_114d0fe7b4dbf15220a2e0b30f642a60>. Acesso em: 10 dez. 2017.

DOEL, T. R. FMD vaccines. Virus Research, Amsterdam, v. 91, p. 81-99, 2003. Disponível em: $\quad$ https://ac.els-cdn.com/S0168170202002617/1-s2.0$\underline{\text { S0168170202002617-main.pdf? tid=7fc46acb-1832-4b17-bfe8- }}$ $\underline{1 \mathrm{e} 1 \mathrm{~b} 977 \mathrm{a} 8691 \& a c d n a t=1528304563 \_68345 \mathrm{c} 60 \mathrm{e} 3143 \mathrm{a} 9 \mathrm{c} 9789 \mathrm{f} 97306 \mathrm{edb} 29 \mathrm{~d}>.}$. Acesso em: 10 dez. 2017.

FERREIRA, L. C. L. Impacto da vacinação sobre o desempenho reprodutivo de vacas Nelore multíparas. 2015. 77 f. Tese (Doutorado em Ciência Animal) - Universidade Federal do Mato Grosso do Sul), 2015. Disponível em: $\measuredangle$ https://posgraduacao.ufms.br/portal/trabalho-arquivos/download/2170>. Acesso em: 17 dez. 2017.

FONDEVILA, N. et al. Indicadores seroepidemiologicos para la evaluación de las campañas de control de la fiebre aftosa. Scientific and Technical Review of the Office International des Epizooties, Paris, v. 16, p.784-792, 1997. Disponível em: ४http://wahis2-devt.oie.int/doc/ged/D9389.PDF>. Acesso em: 08 set. 2018.

FORREST, S. et al. Inhibition of the foot-and-mouth disease virus subgenomic replicon by RNA aptamers. The Journal of General Virology, London, v. 95, p. 2649-2657, 2014. Disponível

em: http://www.microbiologyresearch.org/docserver/fulltext/jgv/95/12/2649_vir067751.pdf ?expires=1528306215\&id=id\&accname=guest $\&$ checksum=901B5792A071BF035F5D 59BA080DEB64. Acesso em: 15 dez. 2017.

GRUBMAN, M. J.; BAXT, B. Foot-and-Mouth Disease. Clinical Microbiology Reviews, Washington, v. 17, n. 2, p. 465-493, 2004. 
GRUBMAN, M. J. New approaches to control foot-and-mouth disease: antivirals and novel vaccines. Revista Colombiana de Ciencias Pecuarias, Medellín, v. 19, n. 3, p. 341-346, 2006. Disponível em: < http://www.scielo.org.co/pdf/rccp/v19n3/v19n3a10.pdf>. Acesso em: 10 dez. 2017.

HAMBLIN, C.; BARNETT, I. T. R.; CROWTHER, J. R. A new enzyme-linked immunosorbent assay (ELISA) for the detection of antibodies against foot-and-mouth disease virus. II Application. Journal of Immunological Methods, Amsterdam, v. 93, p. 123-129, 1986. Disponível em: https://ac.els-cdn.com/0022175986904424/1-s2.00022175986904424-main.pdf?_tid=389caf8f-b9f5-486e-8084-

7ea9d043f849\&acdnat $=1528306021 \quad 39 \mathrm{c} 4940 \mathrm{ce} 1 \mathrm{bbeca} 42469 \mathrm{bcf3bc80dfe0}>. \quad$ Acesso em: 10 dez. 2017.

IICA - INSTITUTO INTERAMERICANO DE CCOPERACIÓN PARA LA AGRICULTURA. Manual de tecnicas de laboratório para el diagnostico en salud animal. 2001. Disponível em: $\langle$ https://books.google.com.br/books?id=WZcOAQAAIAAJ>. Acesso em: 20 mar. 2018. JAMAL, S. M.; BELSHAM, G. J. Foot-and-mouth disease: past, present and future. Veterinary Research, London, v. 44, p. 116. 2013. Disponível em: < https://www.ncbi.nlm.nih.gov/pmc/articles/PMC4028749/pdf/1297-9716-44-116.pdf>. Acesso em: 20 nov. 2017.

KAHN, S.; GEALE, D. W.; KITCHING, P. R.; BOUFFARD, A.; ALlARD, D. G.; DUNCAN, J. R. Vaccination against foot-and-mouth disease: the implications for Canada. Canadian Veterinary Journal, Ottawa, v. 43, p. 349 - 354, 2002. Disponível em: < https://www.ncbi.nlm.nih.gov/pmc/articles/PMC339268/\#r25-22>. Acesso em: 26 set. 2018 .

KNIGHT-JONES, T.J.D.; RUSHTON, J. The economic impacts of foot and mouth disease - What are they, how big are they and where do they occur? Preventive Veterinary Medicine, Amsterdam, v. 112, p. 161 - 173, 2013. Disponível em: < https://ac.els-cdn.com/S0167587713002390/1-s2.0-S0167587713002390main.pdf?_tid=de9f5811-2f9e-4ea0-a471e87fdbe91ad9\&acdnat=1538143619 74d702ee23a7ee85b6b7607a1a8be8dc >. Acesso em: 27 set. 2018. 
LEW, R. A.; LEVY, P. S. Estimation of prevalence on the basis of screening tests. Statistics in Medicine, New York, v. 8, n. 10, p. 1225-1230, 1989.

LONGJAM, N. et al. A brief review on diagnosis of foot-and-mouth disease of livestock: conventional to molecular tools. Veterinary Medicine International, New York, v. 2011, p.1-17, 2011. Disponível em: https://www.ncbi.nlm.nih.gov/pmc/articles/PMC3135314/pdf/VMI2011-905768.pdf>. Acesso em: 25 nov. 2017.

LUCAM, F.; FÉDIDA, M. Une nouvelle méthode quantitative pour l'appréciation de l'immunité anti-aphteuse. Bulletin - Office international des épizooties, Paris, v. 49, p. 596-621, 1958.

LYRA, T. M. P.; SILVA, J. A. A febre aftosa no Brasil, 1960-2002. Arquivo Brasileiro de Medicina Veterinária e Zootecnia, Belo Horizonte, v. 56, n. 5, p. 565-576, 2004. Disponível em: 〈http://www.scielo.br/pdf/abmvz/v56n5/a01v56n5.pdf>. Acesso em: 25 nov. 2016.

MAPA. Ministério da Agricultura, Pecuária e Abastecimento. Orientações para fiscalização do comércio de vacinas contra a febre aftosa e para controle e avaliação das etapas de vacinação. 2005. Disponível em: < http://www.agricultura.gov.br/assuntos/sanidade-animal-e-vegetal/saudeanimal/programas-de-saude-animal/febre-aftosa/documentos-febre-aftosa/orientacoespara-fiscalizacao-do-comercio-de-vacinas-contra-a-febre-aftosa-e-para-controle-eavaliacao-das-etapas-de-vacinacao.pdf>. Acesso em: 09 set. 2018.

MAPA. Ministério da Agricultura, Pecuária e Abastecimento. Avaliação da imunidade populacional resultante das campanhas de vacinação contra a febre aftosa. 2007. Disponível em: <http://www.agricultura.gov.br/assuntos/sanidade-animal-evegetal/saude-animal/programas-de-saude-animal/febre-aftosa/documentos-febreaftosa/avaliacao-da-imunidade-populacional-resultante-das-campanhas-de-vacinacaocontra-a-febre-aftosa-2005-2006.pdf>. Acesso em: 31 out. 2017.

MAPA. Ministério da Agricultura, Pecuária e Abastecimento. Manual de Padronização do Departamento de Saúde Animal, versão 18.0. 2014a. Disponível em: $<$ http://www.agricultura.gov.br/assuntos/sanidade-animal-e-vegetal/saude- 
animal/transito-animal/arquivos-transito-internacional/ManualdePadronizao18.0.pdf>. Acesso em: 20 mar. 2017.

MAPA. Ministério da Agricultura, Pecuária e Abastecimento. Estudo epidemiológico para avaliação da eficiência da vacinação contra febre aftosa na zona livre - Manual de padronização de atividades. 2014b. Disponível em: < http://www.agricultura.gov.br/assuntos/sanidade-animal-e-vegetal/saudeanimal/programas-de-saude-animal/febre-aftosa/documentos-febre-aftosa/estudosorologico-para-monitoramento-da-eficiencia-da-vacinacao-contra-febre-aftosa-nazona-livre-010.pdf>. Acesso em: 15 jul. 2017.

MAPA. Ministério da Agricultura, Pecuária e Abastecimento. Monitoramento sorológico para avaliação da eficiência da vacinação contra febre aftosa na zona livre - Relatório final. 2015. Disponível em: <http://www.agricultura.gov.br/assuntos/sanidade-animal-e-vegetal/saudeanimal/programas-de-saude-animal/febre-aftosa/documentos-febreaftosa/monitoramento-sorologico-para-avaliacao-da-eficiencia-da-vacinacao-contrafebre-aftosa-na-zona-livre-2014.pdf>. Acesso em: 15 ago. 2017.

MAPA. Ministério da Agricultura, Pecuária e Abastecimento. Estudo epidemiológico para avaliação de transmissão viral na zona livre de febre aftosa com vacinação. 2016. Disponível em:

<http://www.agricultura.rs.gov.br/upload/arquivos/201706/02151448-relatorio1712573-relatorio-circulacao-viral-zlfa-fev-2016-final-portugues.pdf $>$. Acesso em: 28 set. 2017.

MAPA. Ministério da Agricultura, Pecuária e Abastecimento. Calendário nacional de vacinação de bovinos e bubalinos contra a febre aftosa. 2018. Disponível em: < http://www.agricultura.gov.br/assuntos/sanidade-animal-e-vegetal/saudeanimal/programas-de-saude-animal/febreaftosa/CalendriodeVacinao 2 2018siteMAPA.pdf>. Acesso em: 09 set. 2018.

McCUllOUGH, K. C.; CROWTHER, J. R.; BUTCHER, R. N. A liquid-phase ELISA and its use in the identification of epitopes on foot-and-mouth disease virus antigen. Journal of Virological Methods, Amsterdam, v. 11, p. 329-338, 1985. Disponível em: <https://ac.els-cdn.com/0166093485900266/1-s2.0-0166093485900266- 
main.pdf?_tid=cc951dab-716a-40d9-a21a-

$\underline{944643 b 6 c 1 a e \& a c d n a t=1528308476 \quad 40 a a 0513 d 13 e 1826 f 608 b 48 e f 86 e f 5 b 1>}$. Acesso em: 28 set. 2017.

McKERCHER, P. D.; BACHRACH, H. L. A foot-and-mouth disease vaccine for swine. Canadian Journal of Comparative Medicine, Ottawa, v. 40, p. 67 - 74, 1976. Disponível em: <https://www.ncbi.nlm.nih.gov/pmc/articles/PMC1277520/>. Acesso em: 26 set. 2018.

MELO, C. B.; et al. Bacteria in dairy products in baggage of incoming travelers, Brazil. Emerging Infectious Diseases, Atlanta, v. 20, p. 1933-1935, 2014. Disponível em: < https://www.semanticscholar.org/paper/Bacteria-in-Dairy-Products-in-Baggage-ofIncoming-Melo-Sá/f1795ed7df0fb7b46bec88c59fbb5fee4dfd3627>. Acesso em: 09 set. 2018.

MELO, C. B.; et al. Microbiological detection of bacteria in animal products sized in baggage of international air passengers to Brazil. Preventive Veterinary Medicine, Amsterdam, v. 118, p. 22-27, 2015. Disponível em: < https://www.ncbi.nlm.nih.gov/pubmed/25466683>. Acesso em: 09 set. 2018.

MGAP. Ministerio de Ganaderia, Agricultura y Pesca. Situación de los programas de erradicación de la Fiebre Aftosa de los países en el Continente Americano. 2012. Disponível em:

https://www.paho.org/panaftosa/index.php?option=com_content\&view=article\&id=88:i nforme-de-situacion-de-los-programas-de-erradicacion-de-la-fiebre-aftosa-en-americadel-sur\&Itemid=0>. Acesso em: 09 set. 2018.

MONDRAGÓN, N.; VERA, V.; RESTREPO, G. Evaluación de dos formulaciones de vacuna antiaftosa oleosa bivalente (O1 Campos y 24 Cruzeiro), preparadas com dos sistemas diferentes de purificación y concentración. Revista Colombiana de Ciencias Pecuarias, Medellín, v. 19, n. 4, p. 373-381, 2006. Disponível em: < https://aprendeenlinea.udea.edu.co/revistas/index.php/rccp/article/view/324101/207812 $\underline{84}$ >. Acesso em: 29 set. 2017.

NADER, A. et al. La vacunación antiaftosa con adyuvante oleoso y su influencia en el diagnóstico de la tuberculosis bovina. Revue Scientifique et Technique (International 
Office of Epizootics), Paris, v. 11, n. 3, p. 785-790, 1992. Disponível em: < http://www.oie.int/doc/ged/d9429.pdf>. Acesso em: 15 set. 2017.

OIE. World Organization for Animal Health. Manual of Diagnostic Tests and Vaccines for Terrestrial Animals. 2015. Disponível em: <http://www.oie.int/en/internationalstandard-setting/terrestrial-manual/access-online/>. Acesso em: 13 nov. 2015.

OIE. World Organization for Animal Health. Home > Animal health in the World > Official disease status > Foot and Mouth Disease (FMD)> Map of FMD official status. 2018. Disponível em: <http://www.oie.int/en/animal-health-in-the-world/officialdisease-status/fmd/en-fmd-carte/>. Acesso em: 25 maio 2018.

PACHECO, J. M., MASON, P. W. Evaluation of infectivity and transmission of different Asian foot-and-mouth disease viruses in swine. Journal of Veterinary Science, Seoul, v. $11, \quad$ n. $2, \quad$ p. 133-142, 2010. Disponível em: < http://www.vetsci.org/journal/view.html?volume=11\&number=2\&spage=133 $>$. Acesso em: 25 nov. 2016.

PEREZ, A. M.; WILLEBERG, P. W. Foot-and-Mouth Disease in Swine. Frontiers in Veterinary Science, Lausanne, v. 4, p. 133, 2017. Disponível em: < https://www.ncbi.nlm.nih.gov/pmc/articles/PMC5572059/>. Acesso em: 26 set. 2018.

PINTO, A. A. Erradicação da febre aftosa: mito ou realidade? Disponível em: 〈http://www.dbosul.com.br/pdbos biblioteca materia.asp?arquivo=a2002 02.txt $>$. Acesso em: 13 nov. 2015.

PITUCO, E. M. A importância da febre aftosa em saúde pública. 2012. Disponível em: $<$ http://www.biologico.sp.gov.br/artigos ok.php?id artigo=17>. Acesso em: 13 nov. 2015.

PITUCO, E. M. Febre Aftosa: Revisão de literatura. 2013. Disponível em:< http://faef.revista.inf.br/imagens_arquivos/arquivos_destaque/cQyqLX2hvW9LHur_20 13-6-21-15-44-53.pdf>. Acesso em: 09 set. 2018.

SAMARA, S. I.; BUZINARO, M. G.; CARVALHO, A. A. B. Implicações técnicas da vacinação na resposta imune contra o vírus da febre aftosa. Brazilian Journal of Veterinary Research and Animal Science, São Paulo, v. 41, n. 6, p. 375-378, 2004. 
Disponível em: http://www.scielo.br/pdf/bjvras/v41n6/25244.pdf. Acesso em: 30 jun. 2017.

SENASA. Servicio Nacional de Sanidad Agraria. Estudios serológicos para la estimación de la inmunidad poblacional a fiebre aftosa en el Peru, años 2010 y 2011. 2012. Disponível em: < http://repositorio.senasa.gob.pe/handle/SENASA/125>. Acesso em: 09 set. 2018.

SILVA, R. T.; SANTOS, D. A. Guia para elaboração de dissertações e teses. São Paulo: Secretaria de Agricultura e Abastecimento do Estado de São Paulo, Agência Paulista de Tecnologia dos Agronegócios, Instituto Biológico, Núcleo de Informação e Documentação, 2017. 65 p.

SOBRINO, F. et al. Foot-and-mouth disease virus: a long known virus, but a current threat. Veterinary Research, London, v. 32, p. 1-30, 2001. Disponível em: $\langle$ https://www.vetres.org/articles/vetres/pdf/2001/01/v1103.pdf $>$. Acesso em: 23 mai. 2017.

SOBRINO, F.; DOMINGO, E. Foot-and-mouth disease in Europe. European Molecular Biology Organization reports, Oxford, v. 21, n. 6, p. 459-461, 2001. Disponível em: <https://www.ncbi.nlm.nih.gov/pmc/articles/PMC1083915/pdf/kve122.pdf $>$. Acesso em: 13 mai. 2017.

STENFELDT, C. et al. The pathogenesis of Foot-and-Mouth disease in pigs. Frontiers in Veterinary Science, Lausanne, v. 3, p. 1-12, 2016. Disponível em: <https://www.ncbi.nlm.nih.gov/pmc/articles/PMC4876306/pdf/fvets-03-00041.pdf>. Acesso em: 25 set. 2017.

SUTMOLLER, P. et al. Control and eradication of foot-and-mouth disease. Virus Research, Amsterdam, v. 91, p. 101-144, 2003. Disponível em: <https://www.sciencedirect.com/science/article/pii/S0168170202002629>. Acesso em: 23 set. 2017.

VIANNA FILHO, Y. L. et al. Potency control of foot-and-mouth disease vaccine in cattle. Comparison of the $50 \%$ protective dose and the protection against generalization. Vaccine, Auckland, v. 11, n. 14, p. 1424-1428, 1993. Disponível em: 
〈https://www.sciencedirect.com/science/article/pii/0264410X9390171S >. Acesso em: 23 set. 2017.

ZANELlA, J. R. C.; MORÉS, N.; BARCELlOS, D. E. S. N. Principais ameaças sanitárias endêmicas da cadeia produtiva de suínos no Brasil. Pesquisa Agropecuária Brasileira, Brasília, v. 51, n. 5, p. 443-453, 2016. Disponível em: <http://www.scielo.br/pdf/pab/v51n5/1678-3921-pab-51-05-00443.pdf $>$. Acesso em: 23 mai. 2017. 


\section{ANEXOS}

ANEXO 1 - materiais necessários para a realização do ensaio de ELISA-CFL.

- $\quad$ Placas de microtitulação em poliestireno;

- $\quad$ Lavador de placas;

- $\quad$ Estufa a $37^{\circ} \mathrm{C}$;

- $\quad$ Agitador de placas;

- $\quad$ Agitador de tubos;

- $\quad$ Tubos de vidro e suporte de tubos;

- $\quad$ Micropipetas e cubas;

- $\quad$ Espectrofotômetro;

- $\quad$ Água destilada;

- $\quad$ Amostras para estudo;

- $\quad$ Antígeno de referência;

- $\quad$ Soros de referência controle positivo e negativo;

- $\quad$ Captura- soros hiperimunes de coelho;

- $\quad$ Soro detector- soros hiperimunes de cobaias;

- $\quad$ Conjugado;

- $\quad$ Tampão de diluição;

- $\quad$ Solução de lavado;

- $\quad$ Tampão carbonato/bicarbonato;

- Substrato;

- $\quad$ Ácido sulfúrico 3N;

- Ovoalbumina G II e G V. 